\title{
Polska reklama wydawnicza w dwudziestoleciu międzywojennym. Próba typologii
}

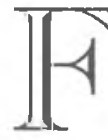

Virmy wydawniczo-księgarskie funkcjonujące na polskim rynku w latach 1918-1939 prowadziły niezwykle zróżnicowane działania zmierzające do upowszechnienia książki i jej popularyzacji wśród potencjalnych odbiorców. Wśród wydawców profesjonalnych stosowanie szeroko pojętej reklamy, tak własnej firmy jak i publikowanych tytułów, stawało się w owym czasie coraz powszechniejsze a wykorzystywane środki wzbogacano i rozwijano. Wiedza o podejmowanych przez wydawców międzywojnia działaniach reklamowych wydaje się być obecnie zupełnie fragmentaryczna i zdecydowanie niepełna. Potrzeba dalszych badań jest w tej sytuacji oczywista, a niniejsza próba typologii ma jedynie na celu usystematyzowanie informacji zawartych w nielicznych monografiach i opracowaniach dotyczących rynku książki lat międzywojennych, wspomnieniach oraz materiałach źródłowych znajdujących się głównie w posiadaniu Biblioteki Narodowej.

Klasyfikacja ta ma za zadanie umożliwienie czytelnego przeglądu rodzajów środków reklamowych stosowanych przez wydawców w latach 19181939. Przy jej opracowaniu wykorzystano koncepcję podziału środków reklamowych autorstwa Tadeusza Hussaka ${ }^{1}$ oraz nowsza, zaproponowaną przez Wojciecha Bytnera ${ }^{2}$, jak również klasyfikacje z okresu dwudziestolecia międzywojennego, głównie autorstwa Stanisława Zenona Zakrzewskiego ${ }^{3}$ oraz Olgierda Langera ${ }^{4}$.

Obfitość materiału źródłowego spowodowała oparcie niniejszej typologii na działaniach reklamowych podejmowanych przez określoną grupę wydawców. Wybrano te firmy wydawnicze, których krąg działań reklamowych był najszerszy i najbardziej zróżnicowany. Z oczywistych powodów były to przedsiębiorstwa największe ${ }^{5}$. Dominowały wydawnictwa warszawskie : Wydawnictwo Gebethner i Wolff, Zakłady Wydawnicze Michała Arcta, Księgarnia Wydawnicza Trzaska, Evert i Michalski (TEiM), Towarzystwo Wydawnicze (Jakuba Mortkowicza), Towarzystwo Wydawnicze „Rój”, Wydawnictwo Jakuba Przeworskiego, Dom Książki Polskiej Z Badań Nad Polskimi Księgozbioram Historycznymi t. 21, Warszawa 2003. 
(DKP), Księgarnia E. Wende i Spółka, Księgarnia Ferdynanda Hoesicka, Spółka Akcyjna „Nasza Księgarnia”, Instytut Wydawniczy „Biblioteka Polska”. Dla uzyskania pełniejszego obrazu dołączono do tego zestawienia lwowsko-warszawską Książnicę-Atlas oraz dwie mniejsze firmy stołeczne: Spółdzielnię Księgarską „Książka” i Powszechną Spółkę Wydawniczą „Płomień", a także 5 znanych wydawnictw z pozostałych największych polskich miast: Wydawnictwo Zakładu Narodowego im. Ossolińskich (Lwów), Państwowe Wydawnictwo Książek Szkolnych (PWKS, Lwów), Księgarnia Św. Wojciecha (Poznań), Krakowska Spółka Wydawnicza (KSW, Kraków), Księgarnia Józefa Zawadzkiego (Wilno). Ponadto uwzględniono przedsięwzięcia reklamowe Polskiego Towarzystwa Wydawców Książek (PTWK), gdyż wydawcy próbowali koordynować działania propagandowe w ramach wzajemnych porozumień oraz na płaszczyźnie funkcjonujących wówczas stowarzyszeń.

Zróżnicowany statut organizacyjny i prawny wymienionych przedsiębiorstw (są wśród nich wydawnictwa państwowe, prywatne, spółdzielcze, spółki, firmy zakładane przez stowarzyszenia i organizacje), rozmaite profile ich działalności, różne środowiska odbiorców, inne drogi kolportażu, sprawiły, iż odmienne były podejmowane przez nie działania promocyjne i reklamowe, co pozwala obecnie na ich porównanie oraz uzyskanie dosyć pełnego obrazu funkcjonowania reklamy wydawniczej w międzywojniu.

Propozycja typologii polskiej reklamy wydawniczej w dwudziestoleciu międzywojennym :

\section{Reklama wizualna pozawydawnicza:}

1. prasowa: *dzienniki, *tygodniki, *czasopisma kierowane do konkretnego odbiorcy i czasopisma fachowe, *czasopisma branży księgarsko-wydawniczej;

2. zewnętrzna: *plakaty i afisze (papierowe i świetlne), *napisy,

*znaki firmowe;

3. reklama w miejscu sprzedaży: *wystawy sklepowe, *regały i reklama wewnątrz (zaaranżowanie wnętrza), * rozmowa sprzedażowa;

4. wizerunek towaru, tu: okładka książki, wizerunki graficzne serii, etc.

II. Reklama wydawnicza (za pomocą wydawnictw sporządzanych specjalnie dla celów reklamowych): *prospekty, *ulotki, *katalogi, *biuletyny, *druki ofertowe, *opaski reklamowe, *zakładki, *spisy oferowanych ksią- 
żek umieszczane na końcu wydanych już publikacji;

\section{Reklama foniczna i audiowizualna:}

1. reklama radiowa w Polskim Radio: *spoty reklamowe, *recenzje;

2. reklama kinowa;

IV. Inne środki reklamowe: *targi, *wystawy, *kiermasze, *spotkania $\mathrm{z}$ autorami;

\section{Działania kreujące korzystny wizerunek firmy:}

1. atrakcyjne formy sprzedaży: *subskrypcja, *prenumerata, *sprzedaż ratalna;

2. przekazywanie gratisów dla bibliotek;

3. fundowanie ksiazżek na nagrody.

Spośród wymienionych powyżej środków reklamowych jedynie reklama prasowa oraz reklama dokonywana za pośrednictwem druków reklamowych jest kojarzona w powszechnej świadomości z działaniami propagandowymi i reklamowymi oficyn wydawniczych międzywojnia. Tymczasem podejmowali już oni wówczas profesjonalne i szeroko zakrojone akcje propagandowe, stosowali bogaty wybór narzędzi reklamowych oraz świadomie kreowali wizerunki swoich firm, jako instytucji działających na rzecz oświaty i kultury. Ze względu na wspomnianą wyżej powszechną dość znajomość druków reklamowych oraz reklamy prasowej z omawianego okresu, w poniższej charakterystyce informacje o tych rodzajach reklamy podano w znacznym skrócie.

\section{Reklama wizualna pozawydawnicza:}

1. prasowa:

Reklama prasowa w okresie polskiego międzywojnia, mimo iż uważana była przez specjalistów za najskuteczniejsze narzędzie reklamy, w rzeczywistości nie była ani szczególnie profesjonalna, ani w pełni wykorzystywana. Wg danych Polskiego Związku Reklamy za 1937 r. tylko 10,1\% powierzchni dzienników i 14,5\% tygodników poświęconych było ogłoszeniom reklamowym. ${ }^{6}$ Powodem tej sytuacji była niewielka liczba polskich koncernów prasowych, a w zwiazku z tym odmienna niż w krajach zachodnich kalkulacja kosztów, opierająca się nie na wpływach z reklam, a głównie na prenumeracie. Brak profesjonalizmu w ogłoszeniach prasowych polegał zaś w dużej mierze na tym, że rzadko powierzano ich opracowanie agencjom reklamowym, których w okresie międzywojennym działało już całkiem sporo 
(m.in. Międzynarodowe Biuro Ogłoszeń (od 1905 r.), Biuro Ogłoszeń Teofila Pietraszka (od 1915 r.), Biuro Ogłoszeń i Reklamy Agencji Telegraficznej, Polska Agencja Reklamy, Dział Reklamy Agencji Telegraficznej Express, Reklama Prasowa, Uniwersalna Agencja Reklamowa i Warszawska Agencja Reklamy). Reklamodawcy najczęściej polegali na usługach działów ogłoszeń poszczególnych wydawnictw prasowych. ${ }^{7}$

Firmy księgarsko-wydawnicze, których część była już całkiem poważnymi przedsiębiorstwami, nie mogły jednak przeznaczać na reklamę prasową tak dużych nakładów jak monopole czy koncerny, których reklamy dominowały w polskiej prasie. W całej masie ogłoszeń i anonsów zamieszczanych na łamach prasy codziennej i tygodniowej, reklam firm księgarskich i wydawniczych znajduje się niewiele.

$\mathrm{Na}$ podstawie przeglądu popularnych dzienników i czasopism $^{8} \mathrm{z}$ lat 1929 i $1938^{9}$, stwierdzić można, iż poza okresami tzw. sezonów księgarskich, reklama książki w prasie była sporadyczna (głównie są to ogłoszenia polecające książki nagrodzone $w$ rozmaitych konkursach oraz edycje słowników, encyklopedii czy dzieł zebranych). Najwięcej ogłoszeń dawano przed świętami Bożego Narodzenia, wakacjami, początkiem roku szkolnego oraz, co obecnie zaskakujące, przed Wielkanocą. Ogłoszenia i reklamy księgarskie były zazwyczaj niewielkie, a jak wiadomo ten czynnik jest jednym z najbardziej decydujących przy ich percepcji (całostronicowe ogłoszenia spotyka się niemal wyłącznie w sezonie gwiazdkowym). Zazwyczaj nie były też ilustrowane.

Całostronicowe i półstronicowe ogłoszenia poświęcano propozycjom sezonowym oraz edycjom pomnikowym i wydaniom dzieł zbiorowych. Drobniejsze (zajmujące 1/4 strony i mniejsze) dotyczyły najczęściej: pojedynczych tytułów, zazwyczaj nowości; czasopism wydawanych przez dane oficyny; wydawnictw ukazujących się w prenumeracie czy subskrypcji; książek nagrodzonych; literatury o określonym przeznaczeniu (dla młodzieży, na lato, nuty, etc.) oraz reklamowały samą firmę i jej usługi. Jednoznacznie stwierdzić można, iż reklamy w dziennikach o zasięgu ogólnopolskim pozostawały domeną dużych firm księgarsko-wydawniczych - Wydawnictwa M. Arcta, Księgarni Wydawniczej Trzaski, Everta i Michalskiego, Towarzystwa Wydawniczego „Rój”, Wydawnictwa Gebethnera i Wolffa. Zdecydowanie największą ilość ogłoszeń różnych typów zamieszczali w gazetach Arctowie, którzy stale przypominali się publiczności, nie zaniedbując ku temu żadnej okazji. 
Tygodniki, przeznaczone dla bardziej wyrobionego czytelnika, zawierały mniej reklam o charakterze ogólnym (polecających słowniki, encyklopedie, przypominających o gwiazdce czy sezonie szkolnym), a zdecydowanie więcej ogłoszeń informujących o poszczególnych nowościach ukazujących się na rynku - zarówno debiutach, jak i o nowych dziełach poczytnych autorów, seriach i cyklach wydawniczych, książkach nagrodzonych, etc. Reklamy wydawnicze w tygodnikach zajmowały zazwyczaj ok. 1/6-1/8 strony. Najbardziej aktywnymi reklamodawcami były wydawnictwa M. Arcta i Gebethnera i Wolffa, a także F. Hoesicka, J. Mortkowicza i „Rój”.

Zwrócić tu należy uwagę na fakt, iż płatne ogłoszenia nie były w tygodnikach jedynym źródłem informacji o książce. Istniały bowiem specjalne działy mające informować czytelników o ukazujących się nowościach, wznowieniach czy innych interesujących publikacjach. Podstawą dla konstruowania tych działów były najczęściej nadsyłane przez wydawców egzemplarze lub materiały reklamowe. I tak Wiadomości Literackie posiadały np. działy: „Nowe powieści”, „Wśród książek”, „Tydzień Bibljograficzny”, „Nowości rynku wydawniczego”, „Książki nadesłane”10; Świat tego rodzaju informacje zamieszczał w rubrykach: „Świat książki” i „Ze świata książki” oraz w dziale „Książki nadesłane" "1; Tygodnik Ilustrowany miał rubrykę o tym samym tytule: „Książki nadesłane" oraz dział "Z ruchu wydawniczego"12. Wszystkie te rubryki pojawiały się jednak w numerach omawianych tygodników raczej sporadycznie, a na pewno żadna z nich nie ukazywała się w każdym numerze.

W tematycznych magazynach ilustrowanych okresu dwudziestolecia międzywojennego niewiele znaleźć można reklam wydawców czy chociażby informacji o książkach. W wydawanym w astronomicznym, jak na ówczesne warunki, nakładzie 250.000 egzemplarzy ${ }^{13}$ Morzu (od 1924r.), gdzie na reklamy przeznaczano kilka ostatnich stron każdego numeru, nie można odnaleźć żadnych reklam wydawniczych. Podobna sytuacja była w Kinie, wydawanym od 1930 r. przez koncern Prasa Polska. ${ }^{14}$ Wyjątek stanowił niespożyty Arct, który w 1930 r. intensywnie reklamował na łamach Kina książkę Tadeusza Miciukiewicza „Tajemnice ekranu”. Oprócz ogłoszeñ ${ }^{15}$, ukazała się tam także pochwalna recenzja ${ }^{16}$ tejże książki, zapewne spowodowana nadesłanym do redakcji egzemplarzem. Również w dziecięcym Plomyku ${ }^{17}$ nie spotyka się reklam książek - informacje o nich zamieszczano w dziale „O książkach”. Prawdopodobnie dział komponowano w oparciu o książki nadesłane do redakcji, omawiano tu $\mathrm{m}$. in. najnowsze publikacje M. Arcta, J. Mortkowicza, Księgarni Św. Wojciecha, Ossolineum, „Naszej Księgarni”, Gebethnera i Wolffa i PWKS ${ }^{18}$. 
Warto zwrócić w tym miejscu uwagę, na jeszcze jeden aspekt reklamy prasowej stosowanej przez wydawców. Pomijając własne biuletyny informacyjne i czasopisma typowo reklamowe, zajmowały się one publikowaniem czasopism ogólnoinformacyjnych, kulturalnych, naukowych, literackich, etc. Łamy tychże czasopism służyły wydawcom do reklamowania własnych i posiadanych na składach tytułów, czasami nawet czyniono to na tyle mało subtelnie, iż narażano się na zarzuty o wydawanie czasopisma reklamowego $^{19}$.

Bardzo popularnym środkiem komunikowania się między wydawcami, hurtownikami, księgarzami i czytającą publicznością były w międzywojniu czasopisma branży księgarsko-wydawniczej. Wydawcami ich bywały najczęściej duże firmy wydawnicze jak Gebethner i Wolff czy Towarzystwo Wydawnicze J. Mortkowicza oraz organizacje i stowarzyszenia z branży (Związek Księgarzy Polskich /ZKP/, PTWK, Związek Zawodowy Pracowników Księgarskich). Istniały wśród nich takie pisma, w których reklamy stanowiły znakomitą większość zawartości, np. Kurjer Księgarski oraz takie, w których było ich bardzo mało lub wręcz nie było wcale, np. Księgarz. Spośród ogłoszeń i reklam zamieszczanych na łamach czasopism wydawniczo-księgarskich z omawianego okresu ${ }^{20}$, wyróżnić można kilka odrębnych typów: reklamy firmy i jej usług; reklamy nowości danej oficyny, najczęściej zaczynające się od słów: ... poleca ostatnie nowości; reklamy określonej kategorii książek, zazwyczaj okolicznościowe (gwiazdka, sezon urlopowy, początek roku szkolnego, święto Niepodległości); reklamy serii; ogłoszenia prenumerat, subskrypcji i sprzedaży ratalnych; reklamy pojedynczych tytułów, z reguły edycji kosztownych lub wyjątkowo popularnych; ogłoszenia o zmianach cen. W znakomitej większości ogłoszenia wielkich firm wydawniczych były cało- lub półstronicowe, a niektóre nawet ilustrowano. Charakterystyczne dla ogłoszeń zamieszczanych we wszystkich branżowych czasopismach było nastawienie na klienta hurtowego. Znakomita większość reklam kierowana była zdecydowanie do księgarzy sortymentystów, niewiele zaś do wydawców (np. reklamy hurtowni i składów głównych) i klientów indywidualnych. Formą popularyzacji własnych publikacji było także przesyłanie do redakcji omawianych periodyków egzemplarzy nowości, które następnie służyły jako źródło informacji umieszczanych w działach takich jak „Nowe wydawnictwa” (Świat Książki) czy „Nowości księgarskie" (Przeglad Bibljograficzny), oraz jako egzemplarze recenzyjne; recenzje zamieszczano m.in. w Świecie Książki i Przeglądzie Ksiegarskim, omówienia zamieszczał też czasem Przeglad Bibljograficzny i Ksiązka. 


\section{2. zewnętrzna:}

a/ plakaty i afisze (papierowe i świetlne):

$\mathrm{O}$ tej formie reklamy niestety nie wiadomo zbyt wiele. Niewatpliwie ją stosowano - świadczy o tym chociażby plakat reklamujący firmę M. Arcta projektu Jana Mucharskiego ${ }^{21}$ czy plakat Gebethnera i Wolffa projektu Mirosława Wisznickiego zachęcający do lektury i prenumeraty Tygodnika Ilustrowanego 22 . Poszukiwania plakatów innych oficyn w zasadzie nie dały rezultatu ${ }^{23}$. Prawdopodobnie, tylko naprawdę duże firmy było stać na opłacenie projektu i druku odpowiedniej ilości egzemplarzy (były one później rozsyłane do współpracujących księgarń sortymentowych ${ }^{24}$ ). Pomniejsze firmy stosowały raczej afisze, co było znacznie tańsze, a zupełnie małe firmy i oddziały lokalne bazowały wręcz na afiszach sporządzanych odręcznie. Biblioteka Narodowa posiada w swoich zbiorach pojedyncze egzemplarze afiszy wydawanych przez DKP, „Rój”, Wydawnictwo J. Przeworskiego oraz M. Arcta.

Prawdopodobnie większość księgarzy wykorzystywała także plakaty, które rozsyłał swoim członkom ZKP. Nie zawsze służyły one propagandzie i reklamie, czasem po prostu informacji, jak np. ten rozesłany do księgarzy w 1929 r.: „Ceny stałe, katalogowe”, który miał ukrócić żądania klientów targujących się i domagających się od sprzedawców rabatów i upustów ${ }^{25}$. Niektóre z plakatów rzeczywiście jednak propagowały książkę; taką rolę pełnił z pewnością plakat projektu Mieczysława Walentynowicza: „Na gwiazdkę książka zastępuje wszystkie upominki" $(50$ x $70 \mathrm{~cm})$, który można było nabyć w biurach ZKP przed świętami Bożego Narodzenia 1937 r. ${ }^{26}$

Aby uczynić plakat bardziej atrakcyjnym i widocznym umieszczano go w podświetlanej gablocie. Często stosowały tę metodę np. kina czy teatry umieszczając owe gabloty $z$ afiszami i fotosami przed wejściami do budynków i sal. ${ }^{27} \mathrm{Na}$ zachowanych fotografiach księgarn i siedzib firm wydawniczych niestety takich podświetleń i gablot nie widać; w prasie i opracowaniach również nie znaleziono informacji na ten temat. ${ }^{28}$

b/ napisy,

Najczęściej stosowanym napisem w reklamie w miejscu sprzedaży jest szyld. Na podstawie zachowanych fotografii księgarń czy budynków firmowych z omawianego okresu, stwierdzić można, iż ówczesny typowy szyld jest literowy (zawierający jedynie nazwę firmy) lub malowany na szybie wystawowej (również tylko nazwa firmy). I tak np. warszawska księgarnia Arctów na Nowym Świecie w Warszawie miała szyld literowy o treści: „M. Arct”29, a księgarnia Gebethnera i Wolffa na Krakowskim Przedmieściu 
takiż szyld „Gebethner i Wolff”. Szyldy-napisy malowane na szybach posiadały z kolei np. filia Gebethnera i Wolffa w Warszawie przy ul. Sienkiewicza („Gebethner i Wolff') ${ }^{30}$ i księgarnia Trzaski, Everta i Michalskiego w Hotelu Europejskim („Księgarnia Trzaska, Evert i Michalski”) $)^{3 !}$.

Napisy firmowe umieszczano także na środkach transportu należących do wydawców. Zachowały się zdjęcia motocykla z przyczepą i samochodu należących do firmy Trzaska, Evert i Michalski, na których widnieją napisy: na przyczepie motoru „Księgarnia Trzaska, Evert i Michalski sp. akc. gmach Hotelu Europejskiego” oraz „Encyklopedia Ilustrowana”; natomiast na pokrywie koła zapasowego samochodu (kapie): „Trzaska, Evert i Michalski, Encyklopedie, Wielkie Wydawnictwa Zbiorowe". ${ }^{32}$ Samochody do rozwożenia pak z książkami posiadał też Gebethner i Wolff, widniały na nich napisy: „Gebethner i Wolff, Warszawa, ul. Zgoda 12"33.

Napisy firmowe $i$ inne używane były również w celach reklamowych wewnątrz księgarń, a także na wystawach książki i przy innych okazjach. Oczywiście stosowano je na drukach reklamowych, papierach firmowych (np. listowych) i książkach.

c/ znaki firmowe;

Graficzny znak firmowy, czyli logo, jest jednym z bardzo istotnych elementów działań reklamowych każdej firmy. Pełni funkcję utrwalającą w pamięci klientów daną firmę, jest czytelnym znakiem rozpoznawczym, który pozwala bez wahania odróżnić produkty firmowe od pozostałych, często symbolizuje ich wysoką jakość. ${ }^{34}$

Spośród wydawców okresu międzywojnia swoje znaki firmowe posiadali $\mathrm{m}$. in.: Gebethner i Wolff (wizerunek sowy okolony wieńcem laurowym), Książnica-Atlas (witeź i książki), J. Mortkowicz (kilka różnych znaków, najsłynniejszy stylizowany kłos pszenicy), Trzaska, Evert i Michalski (Europa jadąca na byku), F. Hoesick (trzy stylizowane kolumny), „Rój" (cztery różne wizerunki, najczęściej trzy pszczoły w ramce), M. Arct (złota jabłoń pochylona nad wizerunkiem słońca wschodzącego znad Starego Miasta Warszawy, napis „prawdą a pracą” i litery MA), IW „Biblioteka Polska” (litery IWBP w owalu), Księgamia Św. Wojciecha (w prostokątnym polu litery KSW, na obrzeżu łacińska sentencja: „Usque dum vivam et ultra") oraz Ossolineum (wizerunek budynku i litery ZNIO, używany od ok. 1912 r. $)^{35}$.

Trudno jest dziś ustalić, kto projektował poszczególne znaki graficzne. Wiadomo, że witezia dla Książnicy-Atlasu oraz sowę dla Gebethnera i Wolffa opracował Władysław Skoczylas ${ }^{36}$. Z wieloma grafikami współ- 
pracował J. Mortkowicz, prawdopodobnie pierwszym który zaprojektował dla niego znak kłosa był Jan Bukowski (projekt pochodzi przypuszczalnie z 1909 r.) ${ }^{37}$, inicjał JM wpisany w koło lub kwadrat (cztery niemal równoległe „wężyki”) był pomysłu Adama Półtawskiego, a wykonania Józefa Toma, dwa skrzyżowane snopki narysował Wacław Borowski, zgeometryzowany kłos był autorstwa Stanisława Ostoi-Chrostowskiego. Kolejne projekty opracowywali Edmund Bartłomiejczyk, Wojciech Jastrzębowski i Tadeusz Gronowski. ${ }^{38}$

Zabiegi Mortkowicza poszukującego wciąż nowych rozwiązań, stanowiły z pewnością wyzwanie dla grafików, ale rolę reklamowego znaku pełniła jednak lepiej tkwiąca niewzruszenie w laurowym wieńcu gebethnerowska sowa. Logo umieszczane przez Gebethnera i Wolffa na książkach, reklamowych drukach, samochodach i widniejące nad księgarnią przy ul. Sienkiewicza (kamienna sowa usadowiona tuż nad drzwiami), związało się trwale z nazwą firmy. Niezwykle trwałym okazał się też znak Ossolineum, używany przez tę oficynę po dziś dzień.

3. reklama w miejscu sprzedaży:

a/ wystawy sklepowe,

Omawianie wystaw sklepowych w ramach metod reklamy stosowanych przez oficyny wydawnicze, może z pozoru wydawać się błędne. W rzeczywistości jednak wystawa księgarska uważana była przez wydawców, i nie tylko, za bardzo istotne narzędzie reklamy. Przeglad Księgarski niemal w każdym numerze uświadamiał księgarzom i wydawcom, jak duże znaczenie ma prawidłowo urządzona witryna księgarska. Co miesiąc publikowano „Tematy do dekoracji okien wystawowych”, które pomagać miały księgarzom w prowadzeniu skutecznej akcji propagandowo-reklamowej. Propozycje tematyczne to najczęściej rocznice urodzin i zgonów znaczących postaci współczesnych i historycznych, rocznice ważkich wydarzeń politycznych, święta narodowe polskie i obce oraz zbliżające się sezony na pewne rodzaje publikacji. ${ }^{39} \mathrm{Nie}$ zapominał też Przegląd o dawaniu bardziej przyziemnych wskazówek: ,... nie chodzi tu o nadzwyczajny artyzm $w$ urzadzeniu, bo na to nie każdego stać - ale na czystość i porzqdek każdy się zdobyć może i powinien."

Wszystkie powyższe uwagi kierowane były nie tylko do księgarzysortymentystów, ale i do pracowników księgarń firmowych, gdyż należy pamiętać, że większość firm wydawniczych posiadała wówczas swoje własne księgarnie ${ }^{41}$. Placówki te często dawały wzór do naśladowania pomniejszym księgarniom, jeżeli chodzi o efektowność i estetykę kompo- 
nowania witryn. W Księgarni M. Arcta kierownictwo wręcz zachęcało pracowników do współzawodnictwa w tej dziedzinie (tworzenia oryginalnych i niebanalnych dekoracji witryn), a nawet prowadzono specjalny rejestr fotograficzno-reklamowy tych kompozycji. ${ }^{42}$ Witryny te cieszyły się wielkim powodzeniem wśród publiczności, bywając nawet powodem interwencji policji, gdyż Nowy Świat był wówczas ulicą bardzo ruchliwą, ale wąską, więc przechodnie oglądając wystawę tamowali ruch. ${ }^{43}$

Ekspozycje zaś bywały naprawdę szokujące, jak ta poświęcona Melchiorowi Wańkowiczowi z roku 1934 r., kiedy to wyszły ,...od razu dwie jego ksiqżki: napisane wcześniej, ,, bardzo rdzennie szlacheckie” Szczenięce lata $i$,probolszewicka" Opierzona rewolucja, rezultat wycieczki do Zwiqzku Radzieckiego. (...) Lubując się (...) w epatowaniu opinii publicznej Wańkowicz tak synchronizuje wydanie tych ksiaziek, by ukazały sie jednocześnie. Jeszcze gorzej - prezentuje je publiczności w sposób szczególny: (W księgarni Arcta) pót okna wystawowego na zielono - byty tam rozłożone Szczenięce lata z okladkq z drzewem genealogicznym Wańkowiczów (...). Pól zaś okna zawality czerwone okladki Opierzonej rewolucji z sierpem, mlotem i napisami „Proletariusze wszystkich krajów tązcie się” w kilkunastu językach. Na miedzy, między tym zielonym i czerwonym polem, rosto wielkie drzewo genealogiczne zrobione przez Daszewskiego z papier maché, z którego pękata figurka Wańkowicza zdejmowala tarczę heraldyczna Jerzego ożenionego z Sofka Gedyminowiczówna, i zawieszala na jej miejsce gwiazdę bolszewicka. Zaraz po tym począl się cyrk niesamowity..."44

Oprócz Arcta z nadzwyczaj efektownych wystaw okiennych słynęła warszawska księgarnia Książnicy-Atlasu. W 1932 r. prasa pisała: „Trzeba pójść i zobaczyć ... Pod księgarniq Ksiqżnica-Atlas na Nowym Świecie 59 gromadza się codziennie grupki publiczności, z zajęciem przygladając się wielkiej wystawie. Trzeba przyznać, że wystawa ta urzadzona jest niezwykle pomystowo. Znam ludzi, którzy co pewien czas idqna Nowy Świat żeby przekonać się co nowego księgarnia wymyślita. Oto np. obecna wystawa księgarni prezentuje wielkie mapy, przedstawiające obie pólkule naszego globu. $\mathrm{Na}$ nich jakieś kóteczka, krateczki. Z boku objaśnienia latwe, proste, zrozumiate. Okazuje się, że jest to mapa walutowa świata. Inaczej oznaczone sq kraje majace walute o pelnym pokryciu zlota, inaczej kraje o walucie chwiejnej, inaczej wreszcie kraje, które odstapily ostatnio od standardu zlota... Najróżniejsze już rzeczy pokazywano nam w S.A. Ksiqżnica-Atlas. Pewnego dnia byla tu np. mapa monarchii w Europie... Raz znów pokazano na mapie katastrofę statku Cieszyn... Innym razem $w$ niezwykle pomyslowy, zgrabny 
sposób zilustrowano na mapie wyniki wyborów prezydenckich $w$ Niemczech i pokazano, jak na dtoni, jak wielkie sq szanse Hitlera wtaśnie w Prusach i innych krajach zwiqzkowych." 45

Oryginalne witryny miewały także księgarnie Gebethnera i Wolffa, który np. w 1929 r. wystawił „,ruchome figurynki charakterystyczne, wychodzące z księgarni z katalogami firmowemi”. Oczywiście przy niej także gromadzili się przechodnie, gdyż jak wiadomo „efekty ruchowe zawsze zatrzymują widza"46.

Firmy wydawnicze nie poprzestawały jednak na zainteresowaniu wyglądem okien wystawowych własnych lokali, ale dbały również o to, aby księgarnie sortymentowe prezentowały w należyty i interesujący sposób sprzedawane nakłady ${ }^{47}$. Najpopularniejszą metodą zachęcenia księgarzy do organizowania estetycznych i reklamujących pożądane tytuły wystaw, było ogłaszanie konkursów na najlepsze okno wystawowe. Konkursy takie, oprócz tych, inicjowanych przez wydawców, ogłaszał też m.in. Związek Księgarzy Polskich. W 1938 r. z okazji 80-lecia firmy Gebethner i Wolff, został ogłoszony Ogólnopolski Konkurs Wystaw Okiennych, poświęcony wydawnictwom tej firmy - jego realizacja nie wypadła najlepiej. Mieczysław Fuksiewicz (członek ZKP) pisał wówczas: „Z przykrościq podkreślić należy ogólny niski poziom, brak pomystowości w urzadzaniu wystaw przez firmy warszawskie, jak również mate zainteresowanie Konkursem. Księgarstwo prowincjonalne wykazalo duże wyrobienie zawodowe, realizujac szczęśliwy pomyst Gebethnera i Wolffa. (...) Wysilek tych firm winien dać dobre rezultaty, gdyż wystawy urzq̨dzane z poczuciem piękna, a szczególniej wystawy specjalne na prowincji, maja duż sile przyciagajaca i sa odskoczniq od szarego dnia, w którym wszystko ptynie wolniej aniżeli w stolicy. (...) Dobrze urzadzona wystawa, to najlepszy instrument propagandy dla firmy i wystawianych wydawnictw."48 W 1936 r. ogólnokrajowy konkurs wystawy okiennej ogłosiła Książnica-Atlas. W jego wyniku przyznano dwie równorzędne nagrody honorowe księgarniom M. Arcta oraz Gebethnera i Wolffa. Trzecią nagrodę honorową zdobyła Księgarnia Wł. Michalak i S-ka. ${ }^{49}$

ZKP ogłaszał też konkursy fotograficzne wystaw okiennych (pierwszy pod koniec 1928 r., kolejny w kwietniu 1929 r.), ale nie cieszyły się one wielką popularnością ${ }^{50}$. Wydaje się, że chętniej uczestniczyli księgarze w konkursach o charakterze lokalnym, aczkolwiek do konkursu ogłoszonego w Wilnie w 1937 r. przystapiło zaledwie 5 firm (I nagroda - Księgarnia „Naszej Księgarni”, II - Księgarnia Gebethnera i Wolffa, III - Księgarnia J. Zawadzkiego). ${ }^{51}$ Jednym z pierwszych takich przeglądów konkur- 
sowych był warszawski, towarzyszący „Wystawie Księgarskiej” w Resursie Obywatelskiej oraz Zjazdowi Powszechnego Związku Właścicieli Księgarn w Polsce w 1925 r. Sąd konkursowy stwierdził, że: ,poza trzema firmami bodaj ani jedna z ksiegarń nie posiada dostatecznie sprzyjajacych warunków do dekorowania okien" oraz orzekt iż ,większość naszych księgarskich zdobniczych żyje arcyubogiemi pomystami dawniej ustalonych wzorów i na oryginalność rzadko umie się zdobyć". Jednak, pier"wszq tę próbę w kierunku zeuropeizowania witryny księgarskiej" powitano z uznaniem i nagrodzono: firme „Ignis”, Gebethnera i Wolffa (ul. Sienna), Towarzystwo Wydawnicze, M. Arcta, Trzaskę i Michalskiego oraz Książnicę ${ }^{52}$.

W 1938 r. koło warszawskie ZKP zorganizowało dla swoich członków konkurs ${ }^{53}$ wystaw okiennych księgarn miejscowych, na który należało przygotować wystawę dotyczącą: a) jednej książki, b) książek z jednej dziedziny, c) nowości lub książek z różnych dziedzin. Zgłosiło się dwunastu uczestników, spośród których nagrodzono następujące firmy: Trzaskę, Everta i Michalskiego, M. Arcta oraz księgarnie Gebethnera i Wolffa na ul. Sienkiewicza i Krakowskim Przedmieściu.

Oprócz ogłaszanych konkursów Zarząd Koła Warszawskiego ZKP od 1928 r. organizował co pewien czas ,przegląd wystaw bez uprzedniej zapowiedzi, w celu sprawdzenia, jak to nie dla popisu jednorazowego lecz we własnym interesie dbają księgarnie warszawskie o ten czynnik reklamy i propagandy". W grudniu 1929 r. dokonano takiego przeglądu i, podobnie jak w konkursach, przyznano nagrody: I - M. Arct, II - księgarnia M. Szczepkowskiego (oddział Księgarni Św. Wojciecha), III - księgarnia K. Szylinga. ${ }^{54}$

W zasadzie wszystkie większe i liczące się na ówczesnym rynku oficyny wydawnicze, nie tylko wykorzystywały możliwości jakie dawała im reklama poprzez witryny księgarskie, ale również były przykładem dla mniejszych firm, wskazując im jak skutecznie propagować swoje nakłady i sortyment. Zdobywane przez nie nagrody ${ }^{55}$ i uczestnictwo w ogłaszanych przeglądach witryn dowodzą wysokiego poziomu realizowanych przez te firmy projektów propagandowych.

b/ regały i reklama wewnątrz (zaaranżowanie wnętrza),

W omawianym okresie większość placówek dysponowała lokalami niewielkimi, co wiązało się niewątpliwie z trudnościami finansowymi z jakimi borykano się wówczas na rynku księgarskim ${ }^{56}$. Rozmiary sali sprzedażowej w decydujący sposób wpływały na sposób urządzenia wnętrza, ekspozycję książek i stosowane formy reklamy. Typowa księgarnia z okresu 
dwudziestolecia międzywojennego wyposażona była w półki na książki rozmieszczone na wszystkich ścianach, poprzez całą wysokość pomieszczenia, do samego sufitu, który najczęściej znajdował się na wysokości 3,5-4 metrów. Książki ustawione były na takich regałach ciasno, jedna przy drugiej, grzbietami do klienta, co oczywiście nie sprzyjało prezentowaniu okładki. Od klienteli oddzielały owe półki szerokie i dość wysokie lady księgarskie. Dodatkowym umeblowaniem były często krzesła dla klientów, a czasem nawet stoliki ${ }^{57}$.

Takie urządzenie księgarni sprzyjało reklamie książki poprzez rozmowę sprzedażową oraz wystawy okienne, aczkolwiek często okna były nieliczne, co ograniczało możliwości propagowania wydawnictw tą drogą ${ }^{58}$. Księgarze starali się jednak za wszelką cenę powiększać powierzchnię wystawową: przy Księgarni M. Arcta ustawiano dodatkowe witryny przypominające oszklone szafy, które wypełniały przestrzeń między jednym a drugim oknem wystawowym ${ }^{59}$; w księgarni Mortkowicza zaś pogłębiano witryny zwyczajnym arkuszem dykty wspartym o stołek ${ }^{60}$. Niewielka liczba witryn oznaczała też, że wnętrza księgarń musiały być dość słabo oświetlone.

Pracownicy księgarń dokładali jednak wszelkich starań, aby mimo trudności, książkę reklamować. W księgarni Arcta stale na ladach i kontuarach urządzane były wystawki ${ }^{61}$. Organizowano też specjalne działy, na które chciano szczególnie zwrócić uwagę klienta, np. działy nowości czy książek po cenach obniżonych („,Tani bazar" u Arcta) ${ }^{62}$. Dodatkową możliwość ekspozycji stwarzały w księgarniach oszklone szafy pełniące rolę gablot wystawienniczych, a także chroniące przed zniszczeniem cenniejsze edycje. W niektórych księgarniach ustawiano specjalne lady - przeszklone od góry, bądź od frontu - które umożliwiały stałą prezentację wydawnictw, a jednocześnie nie utrudniały obsługi klienta ${ }^{63}$. Wykorzystywano także stojące w niektórych lokalach stoły i stoliki, eksponując na nich nowości lub publikacje, na które chciano zwrócić szczególną uwagę $e^{64}$.

Zdarzały się odstępstwa od tradycyjnego stylu urządzenia księgarn, np. w księgarni TEiM, gdzie wprowadzono wolny dostęp do półek. Książki układano tu tak, aby łatwo było dotrzeć do poszczególnych egzemplarzy oraz w taki sposób, aby wydawnictwa TEiM znajdowały się na pierwszym planie ${ }^{65}$. Nowości wyeksponowane były osobno, wystawka ta była często zmieniana, lecz zawsze zaopatrzona w odpowiednią kartkę np. z napisem: Książki najwybitniejsze i książki o których się mówi. ${ }^{66}$ Wyjątkowo piękne wnętrze miała w owym okresie księgarnia IW „Biblioteka Polska”, uważa- 
na za najbardziej reprezentacyjną i efektowną. Na fotografii z 1926 r. widać przestronne, jasne wysokie sale o starannym umeblowaniu. Regały z książkami ukryte zostały we wnękach, pośrodku sal ustawiono duże stoły z książkami, na ścianach zawieszono kinkiety. Dominowało wrażenie przestrzeni i świałła. Niestety w okresie wielkiego kryzysu (1929-1932), firma przeżywała trudności finansowe i zmuszona została księgarnię przenieść do mniejszego lokalu. ${ }^{67}$

Firmy urządzały też w swoich placówkach rozmaite wystawy. DKP ze względu na swoją specyfikę (księgarnia hurtowa) organizował często wystawy mające na celu wyodrębnienie pewnych grup tytułów ze swoich ogromnych magazynów, zaprezentowanie ich sortymentystom i publiczności, wreszcie - sprzedaż. Tylko w ostatnim kwartale 1936 r. odbyły się trzy takie wystawy - książek technicznych (,1000 książek z techniki, mechaniki, rzemiosła, budownictwa i komunikacji”), tanich oraz książek gwiazdkowych. Dla publiczności wstęp był bezpłatny ${ }^{68}$. Do codziennej ekspozycji posiadanych nakładów służyły DKP tymczasowe wystawy nowości oraz wzorownia. ${ }^{69}$

Zupełnie odmienny charakter miały ekspozycje przygotowywane w małej księgarni J. Mortkowicza. Prezentowano tam najczęściej reprodukcje artystyczne i wydawnictwa z zakresu sztuki, które szczególnie interesowały właściciela. Ponadto Mortkowicz organizował w księgarni wystawy oryginalnych prac malarskich młodych artystów warszawskich (m.in. A. Słonimskiego). Wystawy te popularyzowały placówkę na Mazowieckiej jako księgarnię literacko-artystyczną gdzie spotykali się przedstawiciele środowisk twórczych i inteligencji ${ }^{70}$.

Specjalne dekoracje i wystawy przygotowywano na sezony handlowe. Zwłaszcza gwiazdka budziła inwencję sprzedawców. Córka Mortkowicza tak wspomina przedświąteczny czas w księgarni: „Wnętrze sklepu zdobily wtedy kwiaty, a potem - kiedy weszly w mode - mate choinki. Na stolach rozkladano najpiękniej oprawne tomy, specjalny stól przy wejściu byt świetnq wystawa wydawnictw dla dzieci" ${ }^{\prime 71}$. Klientów przyciągały do księgarń intensywne akcje reklamowe, duże ogłoszenia w prasie, specjalnie wydawane katalogi, prospekty i plakaty oraz dekoracje witryn. W Wilnie tradycją stało się urządzanie wystawek książek gwiazdkowych w okresie przedświątecznym, patronował im Związek Księgarzy Polskich.

c/ rozmowa sprzedażowa;

Rola, jaką pełni w księgarni wykwalifikowany sprzedawca, znakomicie orientujący się $\mathrm{w}$ asortymencie, potrafiący doradzić, zareklamować 
i sprzedać książkę w sposób szybki, sprawny i kulturalny, a przy tym zrobić to tak, aby zadowolony klient często do księgarni powracał, jest nie do przecenienia. Firmy księgarsko-wydawnicze, nie tylko więc zwracały uwagę na to, kto i w jaki sposób reprezentuje ich interesy w firmowych sklepach, ale podejmowały specjalnie działania mające na celu wykształcenie i przyuczenie do zawodu przyszłych pracowników. Istnieje nawet pogląd, że księgarstwo polskie mogło obywać się tak długo bez specjalnej szkoły dlatego, że szkołę tę niejako zastępowały renomowane firmy, prowadzone przez grono najwytrawniejszych fachowców, ich założycieli i kierowników ${ }^{72}$.

Istotnie, w okresie dwudziestolecia międzywojennego, nie funkcjonowały specjalne szkoły zawodowe dla księgarzy, aczkolwiek czyniono w tej kwestii pewne kroki ${ }^{73}$. Najpopularniejszą metodą kształcenia młodych pracowników, obok szkolenia w miejscu pracy, były kursy księgarskie. Od 1918 r. kursy takie prowadził (nieregularnie) Związek Księgarzy Polskich $^{74}$. Kończyli je pracownicy m.in. Gebethnera i Wolffa, Książnicy-Atlas, Księgarni Św. Wojciecha, Domu Książki Polskiej. ${ }^{75}$ Uczono na nich języka polskiego, historii Polski, encyklopedii nauk, prawa handlowego, buchalterii, księgoznawstwa i księgarstwa, a później także zagadnień bardziej szczegółowych: papiernictwa, drukarstwa, księgarstwa sortymentowego, komis-hurtu, działalności wydawniczej i kolportażu. ${ }^{76}$

Nauka odbywała się prawie zawsze na koszt pracodawcy, ale inwestycje te nie dawały jednak firmie pewnych $\mathrm{i}$ związanych $\mathrm{z}$ nią na stałe pracowników. Wśród sprzedawców-księgarzy panował bowiem, akceptowany w środowisku, zwyczaj "migracji” z firmy do firmy. Każda z nich miała swoisty system pracy i nieco odmienną klientelę, przez co dopiero po zapoznaniu się z funkcjonowaniem kilku większych przedsiębiorstw, młody księgarz opanowywał wszystkie tajniki zawodu. Do macierzystej księgarni wracał (po latach) tylko wówczas gdy się nie usamodzielnił lub nie zajął gdzieś kierowniczego stanowiska. ${ }^{77}$ Taki system kształcenia księgarzy przyczyniał się do wyłaniania spośród nich wybitnych pracowników i był dość korzystny dla całego środowiska księgarskiego.

Gdy fachowy już pracownik stawał na froncie księgarni musiał umieć obsłużyć każdego klienta. Księgarze dzielili ich na specjalne kategorie: klientów stałych, samodzielnych, uciążliwych, „wszystko znających”, ,z fanaberiami”, i po prostu złodziei (tych dzielono na ,szlachetnych bibliofilów" i złodziei zawodowych) ${ }^{78}$. Każdemu trzeba było poświęcić uwagę (chociażby po to aby zapobiec kradzieży), doradzić i pozostawić wrażenie miłej 
i fachowej obsługi. Zdawano sobie sprawę, jak cenny dla firmy jest każdy pojedynczy klient. Sprzedawcy musieli rozpoznawać stałych bywalców, orientować się w ich gustach, upodobaniach i możliwościach finansowych. W księgarniach firmowych konieczna też była taka umiejętność manipulowania klientem, aby w miarę możliwości nabywał on wydawnictwa własne firmy, a jak najmniej sortymentowych.

4. wizerunek towaru, tu: okładka książki, wizerunki graficzne serii, obwoluty, etc.

Okładka książki, jej szata graficzna, jest jednym z najważniejszych instrumentów reklamy wydawniczej. Ma ona za zadanie, oprócz funkcji informacyjnej, zwrócić na siebie uwagę kupującego i zachęcić go do zaku$\mathrm{pu}^{79}$. Świadomość tego faktu była już w dwudziestoleciu międzywojennym na tyle silna, że współpraca między oficynami wydawniczymi a plastykami, grafikami i introligatorami stawała się codziennością.

$\mathrm{Z}$ wybitnymi grafikami i plastykami pracowało wiele oficyn: Wydawnictwo J. Przeworskiego wydawało m.in. książki z ilustracjami Jana Marcina Szancera, Stanisława Bobińskiego, Władysława Daszewskiego, Franciszki Themerson, T. Piotrowskiego, M. Walentynowicza, J. Jankowskiej, J. Mucharskiego, współpracowało ze spółkami Levitt-Him (Jan Levitt, Jerzy Him) oraz „Mewa” (Edward Manteuffel, Antoni Wajwód, Jadwiga Hładko) ${ }^{80}$; z J. Mortkowiczem współpracowali: E. Bartłomiejczyk, Wacław Borowski, Michał Boruciński, J. Bukowski, Tadeusz Cieślewski syn, Zygmunt Kamiński, Stefan Mrożewski, Franciszek Siedlecki, W. Skoczylas, J. Tom, Adam Półtawski ${ }^{81}$; z „Naszą Księgarnia” - S. Bobiński, J. Hładko, Zofia Stryjeńska, W. Telakowska, E. Bartłomiejczyk, Konstanty Sopoćko, Michał Bylina, T. Gronowski, E. Manteuffel ${ }^{82}$; dla „Roju” pracowali: Feliks Topolski, Irena Lorentowicz, Stefan Norblin, T. Gronowski, S. Ostoja-Chrostowski, Zdzisław Czermański, Mieczysław Berman, Kamil Mackiewicz ${ }^{83}$; wydawnictwa Ossolineum ilustrowali K. Mackiewicz, Adam T. Styka, E. Bartłomiejczyk, Kazimierz Kostynowicz, Z. Kamiński, W. Skoczylas ${ }^{84}$.

Niektórzy z nich niewątpliwie opracowywali dla poszczególnych wydawnictw wizerunki graficzne serii (wydawały je wszystkie omawiane oficyny wydawnicze, oczywiście ich tematyka, popularność czy forma edytorska bywały różne - łączyła je tylko koncepcja popularyzacji własnych wydawnictw i chęć związania czytelnika z firmą wydawnicza), aczkolwiek dziś bardzo trudno to stwierdzić. Inną sprawą jest, że często zdobienie okładki (i opracowanie szaty graficznej) polegało jedynie na doborze liternictwa, więc wykonywano owe prace własnym sumptem ${ }^{85}$ lub powierzano tę kwestię drukarniom. 
Wiadomo, że wizerunek słynnej serii „Roju” - „Biblioteczki Historyczno-Geograficznej" projektował E. Bartłomiejczyk ${ }^{86}$. Stosunkowo dokładne informacje mamy o projektach serii wydawanych przez Jakuba Mortkowicza. Znak graficzny serii „Panteon” (Nike w locie) opracował Władysław Husarski, stylizowany rysunek świątyni na okładkach „Plutarcha Polskiego" był autorstwa J. Toma, serie „Biblioteka Beletrystyki” i „Dobre Książki dla Młodzieży” opracował graficznie S. Ostoja-Chrostowski. Co do pozostałych mortkowiczowskich serii nie ma tak dokładnych informacji; do najgłośniejszej z nich „Pod Znakiem Poetów” znak graficzny zaproponował podobno sam wydawca, który mial ponoć przywieźć z podróży po Grecji gipsowy odlew takiej płaskorzeźby. ${ }^{87}$

Współpraca oficyn wydawniczych z grafikami, drukarniami i introligatorami nie dotyczyła oczywiście jedynie serii wydawniczych, a nawet była prawdopodobnie bardziej ścisła przy pojedynczych tytułach; przy seriach liczono bowiem zapewne na „prawo serii”, przy osobnych publikacjach rola okładki czy szaty graficznej zdecydowanie wzrastała. Zwracały na to uwagę nawet te oficyny, które na co dzień nie przywiązywały zbyt dużej wagi do wyglądu swych publikacji, jak np. „Książka”. Na ogół jej wydawnictwa nie były ilustrowane, ale do wielu pozycji okładki projektowali utalentowani plastycy, jak Mieczysław Szczuka czy Teresa Żarnowerówna. Okładki ich autorstwa do wierszy A. Sterna i B. Jasieńskiego „Ziemia na lewo” (pierwsza w Polsce okładka fotomontażowa), książki W. Broniewskiego „Dymy nad miastem" czy wyboru poezji W. Majakowskiego, pozostają dotąd klasycznym przykładem nowoczesnej grafiki okładkowej. ${ }^{88}$

Warto tu może dodać, że w 1938 r. Rada Książki ogłosiła konkurs na okładkę najlepszą pod względem reklamowym. Udział w nim mogły brać tylko osoby pracujące zawodowo w księgarstwie. Wygrała okładka projektu S. Ostoi-Chrostowskiego do „Marysieńki Sobieskiej” T. Boya-Żeleńskiego. Wydawcą książki była Książnica-Atlas. ${ }^{89}$

Nie mniejsze znaczenie miała współpraca z pracowniami introligatorskimi. Przepiękne oprawy wydawnictw mortkowiczowskich wykonywane z najrozmaitszych materiałów były dziełami Roberta Jahody, Bonawentury Lenarta, Franciszka Joachima Radziszewskiego oraz pracowników introligatorni Zofii Dębickiej..$^{90}$ Dla Trzaski, Everta i Michalskiego - firmy znanej $\mathrm{z}$ zamiłowania do pięknych opraw, przygotowywali je: F. J. Radziszewski, Bolesław Zjawiński oraz Introligatornia Artystyczna Wandy Michalskiej (wszystkie te zakłady zdobyły nagrody i dyplomy honorowe na Wystawie Paryskiej w 1937 r.). Zdarzało się i tak, że wybitny nawet introligator 
podejmował się wykonywania opraw nakładowych, co pozwalało obcować ze sztuką książki przeciętnemu czytelnikowi (np. R. Jahoda wykonywał oprawy nakładowe firmy Gebethner i S-ka w Krakowie ${ }^{91}$ ).

Jeżeli książka nie sprzedawała się, stosowano metody mające daną pozycję uatrakcyjnić i uaktualnić. Zdarzało się, że książkę przeoprawiano lub po prostu dodawano obwolutę. Obwoluta była bardzo mile widziana w handlu księgarskim, tak że nawet księgarze postulowali jej stosowanie, motywując to ochroną książki przed zniszczeniem oraz korzyściami reklamowymi. Większość wydawców nie stosowała jednak obwolut, a ci, którzy to czynili, używali ich jedynie przy edycjach szczególnie cennych, tłumacząc to nieopłacalnością. Niektórzy wydawcy wyposażali swoje nakłady w tzw. ślepe obwoluty ( $\mathrm{z}$ białego papieru). Książka będąca długo w obrocie księgarskim, potrzebowała szczególnej ochrony - stąd postulat wydawniczych obwolut (cierpliwsi księgarze wykonywali je sami) ${ }^{92}$. Niewiele oficyn zaopatrywało swoje nakłady od razu w obwoluty drukowane, czynił to np. TEiM w celach reklamowych i zdobniczych. Były one najczęściej barwne, z kredowego papieru; posiadały je z pewnością pomnikowe edycje firmy: „Wielka historia powszechna" czy „Polska, jej dzieje i kultura” oraz seria „Biblioteka Wiedzy" ${ }^{\text {93. }}$.

Warto tu także wspomnieć o często praktykowanym zwyczaju publikowania tej samej pozycji jednocześnie w kilku mutacjach: z większą lub mniejszą ilością ilustracji, na lepszym lub gorszym papierze, w różnych oprawach, co oczywiście wpływało na różnicę w cenie ${ }^{94}$. Wydania tańsze, aczkolwiek bardziej popularne, nie były już tak atrakcyjne graficznie i edytorsko, spełniały jednak ważną funkcję - popularyzowały dzieło.

\section{Reklama wydawnicza (za pomocą wydawnictw sporządzanych spe- cjalnie dla celów reklamowych):}

W okresie międzywojnia na polskim rynku książki funkcjonowało już wiele rodzajów druków reklamowych. Dominowały katalogi księgarskie i wydawnicze, ale odnotować też można dużą grupę prospektów oraz, nieco mniejsza, ulotek i druków ofertowych. Ponadto stosowano też opaski reklamowe i zakładki, rozsyłano listy reklamowe, publikowano biuletyny. Ogółem odnaleziono 1037 (bez biuletynów) egzemplarzy rozmaitych druków reklamowych, wydanych przez omawiane firmy:

a/ prospekty: na największą skalę prospekty stosowały duże oficyny: Wydawnictwo M. Arcta (63), Książnica-Atlas (36), Trzaska, Evert i Michalski (32), IW „Biblioteka Polska” (18), Gebethner i Wolff (16), Wydawnictwo 
J. Mortkowicza (16) i Wydawnictwo J. Przeworskiego (11). Mniej prospektów pozostało po: Krakowskiej Spółce Wydawniczej (8), „Roju” (7), DKP (6), Ossolineum (5), PWKS (5), Księgarni Św. Wojciecha (5), Księgarni J. Zawadzkiego (5), „Naszej Księgarni” (4), Księgarni F. Hoesicka (2), PSW „Płomieńn(1), E. Wende i S-ka (1). Prospekty te różniły się między sobą oprócz treści również aspektami formalnymi: liczbą stron, ilością ilustracji, jakością papieru oraz formatem. Zdarzały się druki o charakterze prospektu przypominające ulotkę $e^{95}$, a można spotkać i takie liczące sobie 16 stron $^{96}$ czy nawet 30 stron $^{97}$. Przeciętnie jednak prospekt wydawniczoksięgarski z tego okresu liczył sobie od 4 do 8 stron. W większości druki te były ilustrowane, zdarzają się jednak takie, których nie ozdobiono żadnymi elementami ilustracyjnymi. ${ }^{98}$ Drukowano je najczęściej na zwykłych papierach, czasem tylko na kredowych lub żeberkowanych. ${ }^{99}$ Format prospektów wahał się od zupełnie niewielkich druczków np. $8 \times 11,5 \mathrm{~cm}$ czy $13 \times 9,5 \mathrm{~cm}^{100}$ do niemal półmetrowych ${ }^{101}$. Za pomocą prospektów reklamowano: słowniki i encyklopedie, wydawnictwa pomnikowe, serie, wydawnictwa zbiorowe, pojedyncze tytuły, nowości, czasopisma, subskrypcje i prenumeraty.

b/ ulotki: zachowało się ich zdecydowanie mniej niż prospektów; udało się odnaleźć jedynie 47 tych druków: 15 ulotek Wydawnictwa M. Arcta, 9 - Gebethnera i Wolffa, 4 -Księgarni Św. Wojciecha, również 4 IW „Biblioteka Polska”, po 3 - „Roju” i Trzaski, Everta i Michalskiego, 2 ulotki Ossolineum, 2 - PWKS, oraz pojedyncze druki Zawadzkiego, Wendego, Książnicy Atlas, KSW i DKP. Ulotki te były bardzo różnych rozmiarów: od niewielkich $(12,5 \times 9,5 \mathrm{~cm} \text { czy } 15 \times 12 \mathrm{~cm})^{102}$ do naprawdę sporych $(38 \times 22 \mathrm{~cm})^{103}$. Zawierały informacje nie tylko dla odbiorców detalicznych, ale także pozwalały sortymentystom staranniej odróżnić napływające nowości od pozostałych tytułów ${ }^{104}$. Ulotki reklamowały najczęściej: nowości, poszczególne tytuły, książki o cenach obniżonych, firmę i jej usługi, książki gwiazdkowe, zaproszenia na wystawy, serie, słowniki, encyklopedie i wydawnictwa pomnikowe.

c/ katalogi: wydawały je wszystkie firmy wydawnicze i zachowało się ich stosunkowo dużo ${ }^{105}$. Oczywiście, tak jak w przypadku innych druków reklamowych, najwięcej zachowało się katalogów dużych firm: Gebethnera i Wolffa (73), Książnicy Atlas (72), Księgarni Św. Wojciecha (71), M. Arcta (56), Ossolineum (51), IW „Biblioteka Polska” (36), KSW (35) oraz „Naszej Księgarni” (31). Mniej katalogów pozostało po Wydawnictwie J. Przeworskiego (27), firmie Mortkowicza (25), Księgarni TEiM (24), Księgarni J. Zawadzkiego (24) i PWKS (22). Niewiele znamy katalogów „Roju” 
(14), DKP (11), „Książki” (9), E. Wendego (8), F. Hoesicka (6) i PSW „Płomień" (2). Udało się też odnaleźć cztery katalogi wydane przez PTWK.

Znakomitą większość spośród wszystkich zachowanych stanowiły katalogi ogólne wydawane zazwyczaj co miesiąc, w układzie alfabetycznym lub działowym, nie ilustrowane, nie adnotowane, formatu ok. $15 \times 11 \mathrm{~cm}$. Stanowiły one podstawową informację o wydanych książkach głównie dla księgarzy sortymentystów ${ }^{106}$. Katalogi kierowane do odbiorcy detalicznego przygotowywane były z większą starannością (zwłaszcza gwiazdkowe), wydawano je na lepszym papierze, czasem ozdabiano ilustracjami, książki dokładnie opisywano i polecano szczególnej uwadze określonych grup czytelników. Były też one bardziej zróżnicowane pod względem formatów, gdyż tę cechę druków również wykorzystywano w celach reklamowych. „Płachty”, „paski” i „miniaturki”107 stanowiły prawdziwą zmorę księgarzy, ale przyciagały wzrok i sprawiały, że zwracano na nie większą uwagę niż na tradycyjne katalogi. W wydawaniu niemal półmetrowych katalogów celował „Rój”, miały one zazwyczaj 4 albo 8 stron i były dość niewygodne w użyciu. Z kolei maleńkie katalogi zdarzało się wydawać Książnicy Atlas. Inne nietypowe formaty, przypominające istotnie „paski” wykorzystywały np. Wydawnictwo J. Mortkowicza, Wydawnictwo J. Przeworskiego, „Rój”, Książnica Atlas.

Pod względem zawartości omawiane katalogi można podzielić na cztery zasadnicze grupy: * katalogi nakładowe, ${ }^{*}$ katalogi komisowe, ${ }^{*}$ katalogi komisowo-nakładowe, * katalogi specjalne: sezonowe, wyprzedażowe, zawierające publikacje z określonej dziedziny, serii.

d/ biuletyny: biuletyny reklamowe i informacyjne były dość popularną formą propagowania własnych wydawnictw i osiągnięć firmy. Różniły się między sobą formą wydawniczą oraz układem i rodzajem zamieszczanych informacji. Z pewnością biuletyny wydawały: DKP (Biuletyn Domu Książki Polskiej), IW „Biblioteka Polska” (Ostatnie nowości własne i komisowe Instytutu Wydawn. „Biblioteka Polska” w Warszawie), Książnica Atlas (Wici, Witeź), Księgarnia F. Hoesicka (Biuletyn Bibliograficzny Wydawnictw Księgarni Ferdynanda Hoesicka w Warszawie), Księgarnia Św. Wojciecha (Biuletyn Wydawniczy Księgarni Św. Wojciecha), Księgarnia Trzaski, Everta i Michalskiego (Biuletyn Medyczny, Biuletyn Techniczny, Katalog nowości Księgarni Trzaski, Everta i Michalskiego, Przegląd piśmiennictwa polskiego i obcego, Przegląd piśmiennictwa obcego), „Nasza Księgarnia” (Dla szkoły i nauczyciela), PWKS (Nowiny Księgarskie, Wieść o książce), Gebethner i Wolff (Biuletyn nowości księgarskich, Nowości Księgarskie), Wydawnic- 
two J. Mortkowicza (Bulletin bibliographique), Wydawnictwo M. Arcta (Biuletyn Michała Arcta, Przegląd wydawniczy).

Biuletyny zawierały bądź informacje o wszystkich nowościach danego wydawnictwa, bądź tylko o tych z wybranych dziedzin, którym poświęcony był druk; wydawano także biuletyny poświęcone publikacjom w danych językach. Oprócz katalogów i druków ofertowych biuletyny były jednym z najważniejszych instrumentów komunikowania się firm wydawniczych $\mathrm{z}$ odbiorcami hurtowymi.

e/ druki ofertowe: nadsyłane były regularnie księgarzom przez wydawców i zawierały całość lub wybór (np. specjalnie z okazji świąt, obniżki cen czy wyprzedaży) oferty tytułowej. Reklama polegała tu raczej na dbałości o zaopatrzenie księgarń, co było ułatwieniem dla księgarzy i w pewnym stopniu zwalniało ich z poszukiwań na własną rękę. Jeżeli chodzi o opracowanie graficzne tych druków, to zazwyczaj nie były one atrakcyjne: papier był gorszej jakości, druk dość niedbały, oczywiście bez elementów zdobniczych. Najwięcej druków ofertowych pozostało po firmie Gebethnera i Wolffa (20); kilkanaście po lubelskim oddziale Księgarni Św. Wojciecha, kilka po DKP, Książnicy Atlas, Księgarni Wendego, Księgarni TEiM, „Naszej Księgarni” i Wydawnictwie Mortkowicza.

f/ opaski reklamowe: opaska jest wyjątkowo nietrwałym drukiem, w związku z czym nie dziwi fakt, iż nie odnaleziono ani jednego egzemplarza. Opaski były jednak stosowane, o czym wiadomo np. ze wzmianek prasowych. W 1929 r. po otrzymaniu przez F. Goetla państwowej nagrody literackiej, wydawca dzieł pisarza - firma Gebethner i Wolff ogłaszała w Przegladzie Księgarskim, iż dostarczy chętnym sortymentystom utwory Goetla zaopatrzone w specjalne opaski. ${ }^{108}$ Natomiast w 1938 r. ZKP zainicjował przeprowadzenie propagandowej akcji letniej pod hasłem: „Książka niezastapiony towarzysz wywczasów", w ramach której wydawcy mieli m.in. wydrukować i przesłać sortymentystom opaski z propagandowymi napisami: „Książka na lato”, „Z książką najlepiej wypoczywać”, itp. ${ }^{109} \mathrm{Nie}-$ stety, są to jedyne potwierdzone informacje o stosowaniu opasek reklamowych przez międzywojennych wydawców.

g/ zakładki: zachowało się bardzo niewiele zakładek i trudno dziś stwierdzić, jakie firmy wydawnicze decydowały się na ich druk. Z całą pewnością wydawały je IW „Biblioteka Polska” oraz Książnica Atlas. Odnaleziono po dwie zakładki każdej z tych oficyn. Zakładki Książnicy Atlas reklamują serię wydawniczą „Biblioteka Iskier” oraz przyrodnicze książki dla młodzieży. IW „Biblioteka Polska” wykorzystała zaś swoje zakładki do polecenia 
subskrypcji na pisma zebrane Adolfa Dygasińskiego oraz do reklamy czytelni C. Witkowskiej ${ }^{10}$ i polecenia własnych publikacji. Zazwyczaj druki te służyły do reklamy publikacji i usług, które pozostawały na stałe w ofercie firmy, gdyż zakładki służą czytelnikom stosunkowo długo i ważne jest, aby przez cały ten czas reklama na nich umieszczana zachowywała aktualność.

h/ spisy umieszczane na końcu wydanych już publikacji: ten sposób reklamy wykorzystywany był przez znakomitą większość firm wydawniczych, tym bardziej, że koszty jej były minimalne. Anonsy i spisy umieszczały na swoich publikacjach m.in. Spółdzielnia Księgarska „Książka”"I1, Księgarnia Trzaski, Everta i Michalskiego, IW „Biblioteka Polska”, Wydawnictwo Gebethnera i Wolffa. Najczęściej spisy książek publikowano w wydawnictwach seryjnych i zawierały one pozostałe pozycje $z$ danej serii (np. w „Bibliotece Automobilisty” /TEiM/, „Wielkiej Bibliotece” /IW „Biblioteka Polska”/, „Biblioteczce Uniwersytetów Ludowych i Młodzieży Szkolnej” /Gebethner i Wolff/). Spisy takie pozwalały też w bardziej zorganizowany sposób kompletować poszczególne tytuły wchodzące w skład danej serii. Natomiast reklamy pojedynczych tytułów umieszczano w książkach o tej samej tematyce, co pozycje reklamowane ${ }^{112}$.

Warto zwrócić jeszcze uwagę na dwa rodzaje drukowanych materiałów reklamowych, a mianowicie na listy reklamowe i wzorniki. Listy reklamowe rozsyłały m.in. Książnica Atlas, „Nasza Księgarnia” i Wydawnictwo M. Arcta. Często adresowano je do dyrektorów szkół, aby polecić najnowsze podręczniki lub też zawiadamiano w ten sposób stałych klientów i prenumeratorów np. o nowych planach wydawniczych czy rozpisaniu kolejnej subskrypcji.

Interesującymi materiałami reklamowymi są wzorniki. Odnaleziono trzy wzorniki publikacji M. Arcta („Historii Powszechnej” A. Szelagowskiego, „Historii Literatury Polskiej” J. Krzyżanowskiego i „Nowoczesnej Encyklopedii Ilustrowanej”) oraz po jednej J. Przeworskiego („Ilustrowana Encyklopedia Powszechna”) i Trzaski, Everta i Michalskiego („Leksykon Ilustrowany"). Były to próbne wydruki danych publikacji, zawierające strony tekstu, tabele, tablice, plansze i ilustracje pochodzące $\mathrm{z}$ danej publikacji. W sumie druk ten zawierał przeciętnie ok. 60 próbnych stron. Oprawa wzornika była wzorem oprawy reklamowanej publikacji (zawsze twarda, co ochraniało wzornik przed zniszczeniem), natomiast na wyklejce mocowano wzory grzbietów w dostępnych wariantach kolorystycznych. Wzorniki były podstawowym narzędziem pracy kolporterów i akwizytorów (wszystkie trzy firmy korzystały z tej formy reklamy i sprzedaży swoich druków), 
którzy mogli potencjalnemu klientowi dokładnie zademonstrować wygląd i zawartość książki, na kupno której zbierali zamówienia.

\section{Reklama foniczna i audiowizualna:}

1. Reklama radiowa w Polskim Radio:

Polskie Radio (PR) rozpoczęło nadawanie 18 kwietnia 1926 r., odtąd audycje nadawane były codziennie. Początkowo był to zaledwie kilkugodzinny program, trwający zazwyczaj od 1700 do 23으 (przeciętnie 6 godz. i 17 min. dziennie, czyli ok. 44 godz. tygodniowo). Około połowy czasu antenowego wypełniała wówczas muzyka ${ }^{113}$, nadawano także transmisje z „Ziemiańskiej”, odczyty, komunikaty, programy dla dzieci oraz „Rozmaitości” (płatne ogłoszenia). Audycje literackie nadawano sporadycznie, najczęściej kosztem programów muzycznych. ${ }^{114} \mathrm{Na}$ początku 1927 r. zdecydowano się uruchomić rozgłośnie regionalne w Krakowie, Poznaniu, Katowicach i Wilnie. W 1929 r. radio miało już 200000 abonentów i nadawało prawie 17000 godz. programu rocznie. ${ }^{115}$ Znakomita większość audycji nadawana była „na żywo”, gdyż aparatura do nagrywania na miękkich płytach Neumanna i taśmie stalowej Stille'a pojawiła się w PR dopiero w 1934 r. ${ }^{116}$

Już w 1926 r. powstał w radiu dział literacko-dramatyczny, który zajął się opracowywaniem słuchowisk, emitowaniem fragmentów powieści „z ilustracją muzyczną” („Kwadranse literackie”), transmisjami z teatrów. Stopniowo pojawiały się inne audycje literackie: „Felietony literackie”, „Kwadranse poetyckie”, „Złote Myśli”."17 Od 1928 r. audycje literackie miały już swoje stałe miejsce: w niedzielę nadawano fragmenty prozy, wtorek zarezerwowany był dla poezji, środa dla nowości wydawniczych, a we czwartki emitowano słuchowiska. Nad całością czuwała komisja, do której należeli m.in. pisarze: W. Sieroszewski, T. Boy-Żeleński, Z. Nałkowska czy J. Kaden-Bandrowski. Z radiem współdziałała duża grupa literatów (co trzeci z nich nawiązał z nim kiedyś współpracę) $)^{118}$, co oczywiście sprzyjało popularyzowaniu literatury i jej twórców. Literaci zajmowali się też wówczas tworzeniem sloganów reklamowych emitowanych m.in. w „Rozmaitościach". Wiadomo, że ich autorami byli np. K. Makuszyński, M. Wańkowicz, J. Kurek i J. Tuwim. Efektem był bardzo wysoki poziom literacki polskich reklam, znacznie wyższy niż np. w reklamie niemieckiej czy francuskiej. ${ }^{119}$

W 1935 r. radio obchodziło dziesięciolecie działalności, miało już 8 radiostacji (oprócz wymienionych - we Lwowie, Lodzi i Toruniu) i ponad 5.000 abonentów, stało się w przeciągu tych lat potężnym środkiem komunikacji 
i propagandy. Niedługo po jubileuszu, w lipcu tegoż roku pakiet większościowy w spółce przejęło państwo - faktycznie było to upaństwowienie radia. Nastapily liczne zmiany, m.in. na stanowisku dyrektora, kierownikiem Wydziału Literackiego został zaś Witold Hulewicz. ${ }^{120}$

Pod kierownictwem Hulewicza, którego zastępcami zostali Jan Parandowski i Zygmunt Kisielewski dział literacki przeżywał dalszy rozwój. To właśnie Parandowski namówił Marię Kuncewiczową do napisania powieści radiowej; powstałe w ten sposób „Dni powszednie państwa Kowalskich", które weszły na antenę 3 listopada 1936 r. i emitowane były odtąd raz w tygodniu, odniosły ogromny sukces. ${ }^{121}$ Kontynuowano nadawanie „Kwadransów literackich”, recenzji, recytacji, spotkań z autorami (cykl „Z mojego warsztatu”) oraz spektakli radiowych.

Dział literacki współpracował z działem oświatowym, prawdopodobnie to właśnie jeden $z$ nich przygotowywał audycje w ramach akcji propagandowych mających na celu upowszechnianie książki i czytelnictwa. Akcje takie organizowało m.in. Ossolineum. W 1939 r. oficyna ta wznowiła „Krzyżaków” Sienkiewicza w niedrogim wydaniu, które postanowiła upowszechnić. O pomoc zwrócono się do wielu czasopism polskich i Polskiego Radia. Radio zgodziło się nadawać codzienne komunikaty, w których informowało o warunkach nabywania „Krzyżaków”. Powieści poświęcono też specjalną audycję, którą wyemitowano 9 sierpnia 1939 r. Akcja musiała odnieść sukces, skoro Ossolineum planowało podobne wydania „Trylogii” i „W pustyni i w puszczy". 122

Radio współpracowało także z Radą Książki, wiadomo np. że w wiosną 1938 r. Rada w porozumieniu z ZKP i PTWK oraz Zrzeszeniami Literatów i Dziennikarzy ogłosiła akcję propagandową pod hasłem „O jedną książkę więcej”, w której radio miało swój udział. Zadaniem tej akcji było, aby w wyniku prowadzonej propagandy ,(...) jak największa liczba obywateli Rzeczypospolitej Polskiej w ciagu tego okresu kupila a przynajmniej przeczytala , o jednq książkę więcej"..."123. PR w tym czasie skoncentrowało zwykłe audycje poświęcone książce w czasie przeznaczonym na akcję propagandowa, nadawało komunikaty Rady Książki o przebiegu akcji oraz organizowało specjalne pogadanki, odczyty i rozmowy na tematy związane z książką. Rada Książki rozważała też możliwość urządzenia konkursu radiowego we współdziałaniu z PTWK, niestety nie wiadomo czy doszło do realizacji tego projektu. ${ }^{124} \mathrm{~W}$ podobnych akcjach brały też udział rozgłośnie regionalne, np. z okazji „Tygodnia Książki Polskiej” (26 X - 3 XII 1933 r.), rozgłośnia wileńska nadała kilka audycji radiowych, m.in. przygotowano 
program pt.: „Jak powstaje książka” transmitowany z drukarni i księgarni Józefa Zawadzkiego. ${ }^{125}$

W 1938 r. Zarząd Główny ZKP wystapił do Polskiego Radia z propozycją współdziałania, które polegać miało na systematycznym udzielaniu ZKP przez PR wyciagów z programów radiowych odnoszących się do audycji o książkach lub poświęconych twórczości poszczególnych pisarzy. Uzyskane informacje ZKP miał zamieszczać z dwulygodniowym wyprzedzeniem na łamach Przeglądu Księgarskiego, w celu umożliwienia księgarzom przygotowania witryny w oparciu o tytuły, które w najbliższym czasie miały być omawiane w radio. Zarząd Główny ZKP zamierzał też zaopatrzyć księgarzy w specjalne, artystycznie wykonane ramki w których umieszczano by wiadomości o zapowiadanych audycjach radiowych dotyczących książki. Nie wiadomo jak potoczyły się dalsze losy tej inicjatywy, ale prawdopodobnie pozostała ona w sferze przygotowań, o ile bowiem wraz z powyższą zapowiedzią ogłoszono, że: „dn. 4 kwietnia br: o godz. $2 l^{\text {th }}$ p. dr Stanislaw Adamczewski omówi w "Nowościach literackich" w Polskim Radio następujace ksiqżki: Artura Górskiego ", Niepokój naszego czasu”, Juljana Krzyżanowskiego „Wladyslaw St. Reymont" oraz pouczono, iż "Pożąane jest, aby księgarnie, posiadajace wymienione książki, wyłożyty je w tym dniu lub w przeddzien w oknach wystawowych z uwagq, ze ksiażki te będq omówione w danym dniu i o podanej godzinie w Polskim Radio." ${ }^{26}$, o tyle następnych podobnych informacji w ciągu całego 1938 r. w Przeglądzie Księgarskim nie zamieszczono.

Zupełnie odrębną formą rek lamy były koncerty reklamowe, które w latach 1930-1931 urządzał i nadawał za pośrednictwem radia Gebethner i Wolff. Pierwszy taki koncert odbył się 19 grudnia 1930 r., brał w nim udział m.in. Mieczysław Fogg. W kolejnych występował też Chór Dana oraz prof. Jerzy Lefeld (fortepian). Na program koncertu składały się: muzyka poważna, muzyka lekka (najnowsze przeboje, znane melodie) oraz informacje o nowych książkach. Księgarzy powiadamiano o mającym się odbyć koncercie za pośrednictwem Wiadomości Księgarskich i wysyłając do nich, razem z ekspedycją książkowa, afisze z programem koncertu (w celu wywieszenia ich w księgarniach). ${ }^{127}$

a/ spoty reklamowe,

Audycje reklamowe pojawiły się w Polskim Radiu w Warszawie już jesienią 1926 r. Płatne ogłoszenia i reklamy nadawano na początku w bloku „Chwilka reklamowa”, a następnie w „Rozmaitościach”. Program emitowano codziennie od godz. $18^{40}$ do $19^{00}$, składał się on z gotowych sloga- 
nów reklamowych przeplatanych muzyką z płyt. ${ }^{128} \mathrm{~W}$ miarę upływu czasu program urozmaicano, a prawdziwy sukces udało się odnieść po zatrudnieniu spikerów - Jerzego Rolanda i Tadeusza Bocheńskiego ${ }^{129}$. Wśród reklamodawców przeważały firmy warszawskie, nie wiadomo niestety nic o ogłoszeniach dawanych przez księgarzy i wydawców. ${ }^{130}$ Udało się jedynie ustalić, że ogłoszenia w „Rozmaitościach" zamieszczał ZKP np. z okazji „Akcji gwiazdkowej” w 1929 r. (codziennie od 18 do 23 grudnia wygłaszano na antenie stosowne przypomnienie). ${ }^{131}$

Rozwój reklamy w PR hamowany był przez działania Polskiego Związku Wydawców Dzienników i Czasopism (PZWDziCz). Narastający powoli konflikı między prasą a radiem przyniósł najpierw ograniczenia w nadawaniu reklam radiowych, a w 1937 r. podpisano porozumienie na mocy którego $\mathrm{z}$ dniem 31 marca $1937 \mathrm{r}$. oficjalnie skasowano reklamę radiową. ${ }^{132}$

$\mathrm{b} /$ recenzje;

Recenzje książek zamieszczane były na antenie PR w ramach programów literackich, m. in. w „Felietonach literackich”. W pierwszej połowie lat trzydziestych „Felietonów...” takich emitowano około stu rocznie, z czego recenzji mniej więcej 20 rocznie; pozostałe felietony poświęcano portretom literackim, zagadnieniom aktualnym, literaturze obcej, zagadnieniom społeczno-literackim, teorii literatury, biografiom etc. Nie wiadomo kto wybierał książki do recenzji - sami krytycy czy rada programowa (komisja) wydziału literackiego. Nie wiadomo też czy wydawcy nadsyłali do radia egzemplarze recenzyjne i czy je wykorzystywano. Wielokrotnie tu cytowany M. J. Kwiatkowski mimo przeprowadzenia szczegółowej analizy programowej nie podaje żadnych dodatkowych informacji na ten temat, brak ich też w monografiach firm.

2. Reklama kinowa (filmy reklamowe, dokumentalne, slajdy):

W latach międzywojennych kino w Polsce cieszyło się wielką popularnością. Szacuje się, iż w latach 1920-1921 działało 400 kin, wyświetlano w nich głównie filmy z importu. ${ }^{133}$ Gdy krajowe wytwórnie rozwinęły produkcję, najwięcej filmów powstawało jako adaptacje literatury. W $1923 \mathrm{r}$. Poznańska Wytwórnia Filmowa zrealizowała „Bartka Zwycięzcę” wg noweli Sienkiewicza, w 1926 r. powstała „Cyganka Aza” (poznańska „Diana-Film”) wg „Chaty za wsią” Kraszewskiego, w 1929 r. nakręcono „Ponad śnieg bielszym się stanę" wg Żeromskiego (koprodukcja Warszawa-Poznań) $)^{134}$, w 1934 r. „Młody las” w oparciu o dramat J.A. Hertza (Warszawa), w 1936 r. „Różę” na podstawie Żeromskiego (Warszawa), w 1937 r. „Dziewczęta z Nowolipek" wg powieści Gojawiczyńskiej (Warszawa) ${ }^{135}$, etc. 
Filmowano dzieła Reymonta („Chłopi” i „Ziemia obiecana”), Żeromskiego („Wierna rzeka”, „Przedwiośnie”), a nawet Mickiewicza („Czaty”, „Pan Tadeusz"). Nie poprzestawano na dziełach pisarzy znanych i uznanych, filmowym tworzywem stawały się też utwory najnowsze: A. Struga (,Mogiła Nieznanego Żołnierza”), F. Goetla („Z dnia na dzień”), I. Zarzyckiej („Dzikuska”). Niektórzy literaci współpracowali z kinem również jako scenarzyści (zawodowym scenarzystą został A. Stern, scenariusze pisali F. Goetel, T. Dołega-Mostowicz, J. Tuwim), współpracownicy (w ekranizacji swych utworów pomagali F. Ossendowski, P. Gojawiczyńska, Z. Nałkowska), a nawet aktorzy (J. Iwaszkiewicz). Tak ścisła współpraca literatów z filmem i odpowiednie jej nagłaśnianie (np. gdy Goetel przygotowywał scenariusz do filmu „Z dnia na dzień” opartego na swojej powieści, w Kinie ukazywały się artykuły na ten temat $\mathrm{i}$ wywiady z pisarzem ${ }^{136}$ ), sprzyjały popularyzacji literatury polskiej, a zarazem reklamowały książki.

Wydawcy wykorzystywali do celów reklamowych fakt sfilmowania powieści. W 1930 r. Trzaska, Evert i Michalski umieścili w Przeglqdzie Literackim następującą reklamę: „Najnowszy film produkcji polskiej: Stefan Kiedrzynski "Serce na ulicy”. Powieść w 2 tomach. Wydanie kompletne."|37, zaś Gebethner i Wolff reklamował swojego autora w Tygodniku Ilustrowanym: "Ostatni polski film zostat osnuty na znanej powieści "Z dnia na dzien" Ferdynanda Goetla, będqcej do nabycia we wszystkich księgarniach"138. "Rój” posunął się w tych poczynaniach jeszcze dalej, mianowicie wydawał serię „Biblioteka Filmowa”, która zawierała jedynie sfilmowane powieści. Ksiąźki te ilustrowano najczęściej fotosami z filmów. ${ }^{139}$

Niestety wydaje się, że były to jedyne kontakty wydawców z filmem i reklamą poprzez film. Nie odnaleziono żadnej wzmianki na temat uczestnictwa którejś z oficyn w produkcji filmów reklamowych czy slajdów. O ile jednak prawdopodobne jest, że żadna $\mathrm{z}$ wielkich firm wydawniczych nie pokusiła się o przygotowanie filmu reklamowego, o tyle udział w kręceniu filmów dokumentalnych czy produkcji przezroczy nie wydaje się być wykluczony.

\section{Inne środki reklamowe:}

1. targi, wystawy, kiermasze,

Okres dwudziestolecia międzywojennego w Polsce obfitował w imprezy wystawiennicze. Znakomita większość znaczących firm księgarsko-wydawniczych brała udział niemal we wszystkich organizowanych wystawach i kiermaszach krajowych i zagranicznych. 
Za pierwszą krajową wystawę książki w niepodległej Polsce, uważa się ekspozycję towarzyszącą I Zjazdowi Księgarzy w 1918 r. w Lublinie. Zorganizowano ją w Bibliotece Publicznej im. H. Łopacińskiego wykorzystując 3.927 druków, które wydane zostały po dniu 1 lipca 1914 r. na ziemiach polskich wszystkich zaborów. Eksponaty podzielono na 10 działów rzeczowych. W zjeździe udział wzięli (a więc prawdopodobnie uczestniczyli też w wystawie) m.in.: Gustaw Wolff, Jarosław Leitgeber, Feliks West, Zygmunt Arct. ${ }^{140}$

W kwietniu 1922 r. urządzono w Warszawie wystawę pod nazwą „Polska Sztuka Drukarska”. Celem prezentacji, na której pokazano druki polskie pochodzące z najlepszych polskich oficyn od XV do XX wieku, było podniesienie poziomu międzywojennego drukarstwa poprzez zademonstrowanie estetyki typograficznej eksponatów. Wystawę współorganizował J. Mortkowicz ${ }^{141}$, a ponadto uczestniczyli w niej: Gebethner i Wolff, IW „Biblioteka Polska”, Ossolineum, Trzaska, Evert i Michalski, Wydawnictwo M. Arcta, Księgarnia Św. Wojciecha, Wende i S-ka, Księgarnia F. Hoesicka i Księgarnia J. Zawadzkiego. ${ }^{142}$

Trzy lata później, w maju 1925 r. we Lwowie tamtejsze koło ZKP urządzito Wystawę Książki Polskiej, mającą pomóc w propagowaniu książki wśród szerszej publiczności. Przedmiotem ekspozycji były wszysıkie tytuły znajdujące się w handlu księgarskim, bez względu na datę ich wydania. Ogółem pokazano 3.600 pozycji 54 wydawców (w tym J. Mortkowicza, który pokazał 115 eksponatów). ${ }^{143}$

Podobne wystawy odbywały się co roku w Warszawie w salach Resursy Obywatelskiej. Wiadomo, że towarzyszyły one zjazdom ZKP, Powszechnego Związku Właścicieli Księgarń w Polsce czy PTWK. Z całą pewnością wystawy te odbyły się w r. 1923 (1 - 4.XI), 1924 (15 - 23.XI), 1926 (30.X - 1.XI), 1927 (30.X - 2.XI), co roku pod innym hasłem np. w 1924 r. , ,Ratujmy książkę" ${ }^{144}$ Brały w nich udział wszystkie liczące się wydawnictwa: Gebethner i Wolff, Trzaska, Evert i Michalski, Ossolineum, M. Arct, Towarzystwo Wydawnicze J. Mortkowicza, DKP, IW „Biblioteka Polska”, Książnica-Atlas, etc. W czasie wystaw odbywała się też sprzedaż książek, stąd zwano je również kiermaszami czy jarmarkami. ${ }^{145}$ Najsłynniejszą z wystaw w Resursie była prezentacja dorobku wydawniczego z pierwszego dziesięciolecia niepodległości, którą otwarto 28 lisıopada 1928 r. pod nazwą: „Książka w Polsce Odrodzonej 1918 - 1928". Zaprezentowały się wszystkie ważniejsze wydawnictwa (członkowie PTWK), przygotowano specjalne druki reklamowe, a organizator, PTWK, rozdał nagrody dla najwybitniejszych krytyków literackich oraz dla wydawców, za najpiękniej wydane książki. ${ }^{146}$ 
W 1929 r. w Poznaniu odbyła się Powszechna Wystawa Krajowa, mająca zaprezentować cały niepodległościowy dorobek przemysłowo-gospodarczy kraju. Księgarze i wydawcy również wzięli udział w tej ekspozycji. Sprawami organizacyjnymi zajęło się PTWK ${ }^{147}$, w wystawie wzięły udział m.in.: Wydawnictwo M. Arcta, Ossolineum, Towarzystwo Wydawnicze J. Mortkowicza, Książnica-Atlas, IW „Biblioteka Polska”, Gebethner i Wolff, „Nasza Księgarnia”, DKP, „Rój” i Drukamia i Księgarnia Św. Wojciecha. Jedno ze stoisk zajeły ZKP i PTWK. ${ }^{148}$ Złote medale, przyznawane przez Ministra Przemysłu i Handlu otrzymali: Gebethner i Wolff, Towarzystwo Wydawnicze w Warszawie, IW „Biblioteka Polska”, M. Arct, Książnica-Atlas oraz Wydawnictwo Polskie R. Wegnera. Ponadto przyznano także cztery srebrne medale i jeden brązowy. ${ }^{149}$

Rok później, w grudniu 1930 r., z inicjatywy Towarzystwa Bibliofilów Łódzkich, zorganizowano w Łodzi Wystawę Współczesnej Książki i Grafiki Polskiej. Wystawa miała zaprezentować możliwości współczesnych technik ilustracyjnych (np. rotograwiury, offsetu, światłodruku) w stosunku do potrzeb książki naukowej i wydawnictw albumowych. Swoje prace przedstawiło 14 wystawców. Spośród firm wydawniczych zaprezentowały się: J. Mortkowicz, DKP, IW „Biblioteka Polska”, Zakłady Graficzne M. Arcta i Gebethner i Wolff. ${ }^{150}$

Wspaniałe oprawy można zaś było podziwiać Warszawie w 1936 r., na Wystawie Pięknej Książki Polskiej towarzyszącej IV Zjazdowi Bibliotekarzy Polskich. Ekspozycję przygotowało Towarzystwo Bibliofilów Polskich $^{151}$. Pokazano prawie 500 druków wydanych od XV do XX wieku, oraz około 200 nowoczesnych opraw. Przeważnie były to wydawnictwa w indywidualnych oprawach, wykonane przez najlepszych polskich introligatorów. Niewiele było opraw wydawniczych, choć prawdopodobnie większość z około 50 mortkowiczowskich książek, wyposażonych było właśnie w oprawy wykonane na zamówienie wydawcy. Pojedyncze oprawy nakładowe pokazały także Książnica-Atlas oraz IW „Biblioteka Polska”. ${ }^{152}$

Oprócz wystaw ogólnopolskich, w których brało udział wiele firm, populamością cieszyły się też wystawy lokalne bądź organizowane przez jedną firmę z okazji rozmaitych świąt, rocznic i wydarzeń kulturalnych. Przykładem mogą tu być ekspozycje organizowane przez Gebethnera i Wolffa (stoisko na wystawie łowieckiej zorganizowanej w 1931 r. w Warszawie ${ }^{153}$, wystawa z 1930 r. urządzona w Krakowie na ogólnopolskim zjeździe polonistów z okazji czterechsetnej rocznicy urodzin Jana Kochanowskiego), Ossolineum (w 1927 r. współorganizowało „Wystawę Pamiątek po Juliuszu Słowackim” 
we Lwowie, a w 1937 r. urządziło wystawę „Lwowska nauka historyczna”. na obu oprócz pamiątek i dokumentów pokazano odpowiednie wydawnictwa. ${ }^{154}$ ) czy Księgarnię Św. Wojciecha (pokaz wydawnictw na wileńskiej Wystawie Mariologicznej w 1937 r.). ${ }^{155}$

Liczne wystawy lokalne towarzyszyły także ogólnopolskiej akcji „Tydzien Książki Polskiej” zorganizowanej z inicjatywy Ministerstwa Wyznań Religijnych i Oświecenia Publicznego w listopadzie 1933 r. Ekspozycje urządzono w wielu polskich miastach: $z$ całą pewnością w Poznaniu (w siedzibie Poznańskiego Towarzystwa Przyjaciół Nauk), w Częstochowie, w Stanisławowie i w Wilnie. ${ }^{156}$

Dorobek edytorstwa i księgarstwa polskiego można było także przez cały okres międzywojnia oglądać na wielu wystawach i imprezach zagranicznych. Pierwszą po wojnie była Międzynarodowa Wystawa Książki we Florencji zorganizowana w maju 1922 r. Udział Polski zgłosił J. Mortkowicz, dopiero później uzyskując zgodę i aprobatę ZKP i Wydziału Prasowego MSZ. W imprezie wzięło udział 53 wystawców z Polski (w tym 27 księgarzy - wydawców). Sekcja polska urządzona była jednak jako dział ogólny w odrębnej sali, bez podziału na firmy. Z pewnością w pokazie florenckim uczestniczyły: Wydawnictwo J. Mortkowicza (72 eksponaty), Gebethner i Wolff (54), Trzaska, Evert i Michalski (3), Ossolineum. ${ }^{157}$

We wrześniu 1924 r. otwarto w Muzeum Książki w Lipsku Wystawę Książki Ozdobnej i Grafiki Polskiej. Miała ona na celu zaprezentowanie tych eksponatów, przy opracowaniu klórych widoczne były motywy narodowe oraz wpływ sztuki ludowej. Stąd na wystawie prace, zresztą później nagrodzone, W. Skoczylasa, J. Pankiewicza, L. Wyczółkowskiego, Z. Stryjeńskiej. Dla Polaków istotne było znaczenie polityczne pokazu, albowiem była to pierwsza, od uzyskania przez nasz kraj niepodległości, prezentacja sztuki polskiej na terenie państwa niemieckiego. ${ }^{158}$

Trzy lata po pierwszej, w maju 1925 r., urządzono II Międzynarodową Wystawę Książki we Florencji, w której wydawcy uczestniczyli na własną rękę, ponieważ rząd nie przyznał na ten cel środków finansowych i nie zgłosił udziału Polski. ${ }^{159}$ Związek Polskich Księgarzy-Wydawców wyznaczył J. Mortkowicza i G. Wolffa na delegatów i organizatorów sekcji polskiej, do udziału w której zgłosiło się 34 wystawców (ekspozycja odbyła się bez podziału na firmy). Dobre położenie polskiej sali oraz efektowne zaprezentowanie eksponatów (projekt i urządzenie Mortkowicza ${ }^{160}$ ), sprawiło, że sekcja polska wzbudzała zainteresowanie i uznanie - przyznano dyplomy 29 polskim wystawcom. ${ }^{161}$ 
W listopadzie tegoż roku, otwarto Wystawę Książki i Grafiki Polskiej w Muzeum Książki w Brukseli. Była ona wspólnym dziełen pracowników Muzeum, Towarzystwa Przyjaciół Belgii w Warszawie, Towarzystwa Bibliofilów Polskich i Stowarzyszenia Polskich Artystów Grafików. Pokazano na niej 280 książek, czasopism, kalendarzy, zaproszeń, prospektów, opraw oraz prac graficznych. Żaden z wydawców nie uczestniczył w tej wystawie bezpośrednio, chętni nadsyłali swoje eksponaty.

W 1925 r. odbyła się jeszcze jedna wystawa zagraniczna w której wzięli udział Polacy - Wystawa Sztuki Dekoracyjnej zorganizowana w Paryżu. Tym razem w dziale polskim nacisk położono na stronę typograficzną eksponatów, co było prawdopodobnie posunięciem słusznym - ekspozycja polska uzyskała na tej wystawie liczne nagrody. ${ }^{162}$

Po raz drugi Polacy mieli możliwość zaprezentowania swoich książek na terenie Niemiec w czerwcu 1927 r. W Muzeum Sztuk Plastycznych w Lipsku Związek Niemieckich Artystów Książki urządził Międzynarodową Wystawę Zdobnictwa Książkowego (Internationale Buchkunst - Ausstellung). Głównym celem wystawy było zaprezentowanie osiagnięć grafików, drukarzy i wydawców w dziedzinie estetyki książki po I wojnie światowej. Pokazano m.in. osiagnięcia E. Bartłomiejczyka, Z. Stryjeńskiej, Z. Kamińskiego, W. Skoczylasa, J. Bukowskiego, A. Półtawskiego i Kazimierza Sichulskiego. Można było podziwiać oprawy wykonane przez: B. Lenarta, R. Jahodę, Jana Recmanika i F. J. Radziszewskiego. Dorobek edytorski pokazało tylko trzech wydawców: J. Mortkowicz, Gebethner i Wolff oraz Ossolineum. W wyniku wystawy czworo Polaków mianowano członkami korespondentami Związku Niemieckich Artystów Książki (Verein Deutschen Buchkünstler); byli to: Skoczylas, Stryjeńska, Kamiński i Mortkowicz. ${ }^{163}$

Rok później Towarzystwo Szerzenia Sztuki Polskiej wśród Obcych zorganizowało Wystawę Sztuki Polskiej w Wiedniu. Jeden z działów poświęcono książce i urządzenie jego ponownie powierzono J. Mortkowiczowi. Niestety nie wiadomo dokładnie ilu wydawców wzięło w niej udział i co pokazano. W tymże 1928 r. w Amsterdamie odbyły się IX Igrzyska Olimpijskie. Z tej okazji przygotowano Olimpijską Wystawę Artystyczn̨ w ramach której odbyło się wiele konkursów. Złoty medal w konkursie literackim otrzymał Kazimierz Wierzyński za zbiór „Laur olimpijski”, należący do mortkowiczowskiej serii „Pod Znakiem Poetów”. Mortkowicz święcił także triumfy w konkursie malarskim, na którym trzecią nagrodę przyznano wydanemu przezeń wielobarwnemu światłodrukowi W. Skoczylasa - „Łucznik”. ${ }^{164}$ 
W maju 1931 r. w Paryżu odbyła się IX Sesja Międzynarodowego Kongresu Wydawców, z okazji której otwarto Międzynarodową Wystawę Książki Artystycznej. Komisarzem po raz ostatni został niestrudzony Mortkowicz. Kierując się zasadą przyjętą przez Francuzów pokazano wyłącznie książki ilustrowane. Polskę reprezentowało na tej wystawie 19 wydawców.

Kolejna ekspozycja polskiej książki to wystawa urządzona w 1932 r. przez duńską firmę księgarską Hassing Boghandel w lokalu własnym w Kopenhadze. W organizacji pomogło tamtejsze poselstwo polskie, oraz polskie firmy wydawnicze, które nadesłały eksponaty. Pokazano wydawnictwa J. Mortkowicza, Trzaski, Everta i Michalskiego oraz lwowskiego Ossolineum. ${ }^{165}$

Ostatnią dużą wystawą przedwojenną była paryska Międzynarodowa Wystawa „Sztuka i Technika” z 1937 r. Polska ekspozycję przygotowało Towa rzystwo Szerzenia Sztuki Polskiej wśród Obcych pod kierownictwem dyrektora, Aleksandra Guttrego. Jeden z działów pawilonu polskiego poświęcono książce ozdobnej, pokazano w nim 135 tomów wydawnictw pochodzących z różnych oficyn wydawniczych. ${ }^{166}$ Największy sukces odniósł Trzaska, Evert i Michalski, firma otrzymała Grand Prix za wydawnictwo „Polska, jej dzieje i kultura”. Nagrodę otrzymał redaktor dzieła Stanisław Lam i współtwórcy ozdobnej oprawy Bogdan i Janusz Kałężni oraz właścicielka Introligatomi Artystycznej - Wanda Michalska. ${ }^{167}$ Ponadto Grand Prix za książkę artystyczną otrzymało Towarzystwo Wydawnicze J. Mortkowicza, a DKP został wyróżniony brązowym medalem za edycje „Lorda Jima” J. Conrada i „Marszałka Józefa Piłsudskiego” W. Sieroszewskiego. ${ }^{168}$

Oficyny wydawnicze często również prezentowały swój dorobek na niewielkich ekspozycjach tematycznych lub wystawach ograniczających liczbę i rodzaj wystawców do ściśle wyselekcjonowanego grona. Przytoczyć tu można przykłady belgijskiej Międzynarodowej Wystawy Spółdzielczości (Gandawa 1924 r.) ) $^{169}$ czy niemieckiej ekspozycji „Goethe w Światowej Sztuce Książki" (1932 r.). ${ }^{170}$

2. spotkania z autorami;

Wykorzystywanie przez księgarzy i wydawców spotkań czytelników, a więc najczęściej nabywców książek, $\mathrm{z}$ ich autorami w celach reklamowych ma niedługą historię. Jeszcze na początku XX w. jedynymi spotkaniami, jakie organizowano w księgarniach były tzw. wenty, podczas których zbierano pieniądze na cele dobroczynne bądź oświatowe. ${ }^{171}$

Nazwa wenty utrzymała się, gdy ówczesny dyrektor Książnicy-Atlasu, dr Jan Piątek wzorem księgarzy paryskich, postanowił organizować 
w firmowej księgarni spotkania autorów z czytelnikami. Odbywały się one jednak bardzo rzadko, mianowicie raz do roku w ostatnią niedzielę przed świętami Bożego Narodzenia, w godzinach popołudniowych. Do księgarni zapraszano kilku autorów i do każdego z nich delegowano jednego pracownika. Pracownik ten miał za zadanie zadbać o wystarczającą ilość egzemplarzy książek „swojego” autora, przyciągnąć odpowiednią reklamą klientów do właściwego stolika oraz tychże klientów obsłużyć. Księgarnię dekorowano, urządzano witrynę, rozsyłano specjalne drukowane zawiadomienia do wybranych osób, a szerszy ogół informowano o wencie dając ogłoszenia w dziennikach.

Wenty musiały cieszyć się popularnością skoro klientela bywała wówczas liczna. W Przeglądzie Księgarskim pisano: „Impreza powiodla się znakomicie. Wnętrze księgarni podczas dwóch godzin, przeznaczonych na podpisywanie, przypominalo najintensywniejszy dzien ruchu szkolnego, z tq tylko różnica że dawal się wyczuwać wśród przybywajacej klienteli nastrój radosny i mile podniecenie, do którego wiele przyczynialo się już na wstępie udekorowanie zewnętrzne księgarni i stosowne wystawy okienne. Publiczność żywo interesowata się imprezq, zwracajac się do obecnych autorów badź to osobiście, bqdź też za pośrednictwem dyrekcji i pracowników. Szczególnem powodzeniem cieszyl się Eysmond, który nie szczędzil pióra, zaopatrując niektóre książki w arcydowcipne autografy. Lacznie podpisal Eysmond okolo 250 swoich dziet."172

W wentach Książnicy-Atlasu udział brali znakomici i popularni pisarze i poeci międzywojnia: J. Tuwim, L. Staff, Z. Nałkowska, M. Dąbrowska, K. Makuszyński, Z. Kossak-Szczucka, K. Wierzyński, H. Boguszewska, M. Rusinek, J. Wiktor, J. Wołoszynowski, M. Lepecki, J. Ejsmond i J. Meissner, Z. Dębicki, F. Goetel, L. Pomirowski, M. Smolarski, F. Ossendowski, S. Malec. ${ }^{173}$

Podobnych spotkań zapewne nie urządzano wcześniej, tj. przed grudniem 1929 r., skoro w Przeglądzie Księgarskim nazywa się je inicjatywą zasługującą na uwagę i pochwałę, i przypomina, że wielokrotnie na tychże łamach poruszano kwestię zorganizowania na wzór zagranicy tzw. ,sprzedaży autografów autorskich". ${ }^{174} \mathrm{O}$ ile jednak Książnica-Atlas spotkania te kontynuowała, o tyle w prasie codziennej i czasopismach branżowych nie ma informacji dotyczących organizowania podobnych imprez przez jakąkolwiek firmę księgarską czy wydawniczą tego okresu.

Odmienny charakter miały wieczory organizowane w latach 1924 - 1939 przez Księgarnię Trzaski, Everta i Michalskiego. Głównym celem, jaki sta- 
wiała sobie firma przy urządzaniu tych spotkań było popularyzowanie nauki i rozwój kultury czytelniczej. Zapraszano uczonych i wynalazców, najczęściej autorów dzieł wydanych nakładem firmy, dyskutowano o planach wydawniczych, recenzowano te książki, które już się ukazały, rozprawiano o rozwoju kultury w Warszawie i całej Polsce ${ }^{175}$. Niestety nie wiadomo czy spotkania te miały charakter otwarty, czy brali w nich udział tylko zaproszeni goście.

\section{Działania kreujące korzystny wizerunek firmy:}

Firmy wydawniczo - księgarskie dwudziestolecia międzywojennego, dbały o to, aby postrzegano je jako instytucje propagujące oświatę i czytelnictwo, będące współtwórcami sukcesów literackich pisarzy, autorami dzieł sztuki - pięknych, artystycznych książek i inspiratorami powstawania wiekopomnych utworów i edycji, pełniące funkcję kreatorów i mecenasów kultury. W tym celu stosowano cały szereg rozmaitych zabiegów mających kształtować taki wizerunek firmy.

Chęınie wykorzystywaną metodą było informowanie publiczności o nagrodach i wyróżnieniach, zarówno tych, kióre otrzymywała sama firma, jak i tych, którymi nagradzano publikujących w danej oficynie pisarzy. „Rój”" reklamował w ten sposób najczęściej książki laureatów nagrody Nobla ${ }^{176}$, a Mortkowicz autorów wyróżnianych w kraju i za granicą (np. K. Wierzyńskiego, L. Staffa, J. Tuwima). ${ }^{177}$ Cytowano przy tym opinie sędziów i fragmenty entuzjastycznych recenzji prasowych. Podobne działania podejmowało też Wydawnictwo F. Hoesicka ${ }^{178}$, Księgarnia Wydawnicza Trzaski, Everta i Michalskiego ${ }^{179}$ czy Gebethner i Wolff (m.in. kampania reklamowa twórczości F. Goetla po otrzymaniu przezeń nagrody państwowej w 1929r.). ${ }^{180}$

Równie ważna, czasami może ważniejsza od blichtru nie zawsze wartościowych nagród ${ }^{181}$, była codzienna praca na rzecz pozyskiwania nowych i utrzymywania stałych klientów. Aby przyciagnąć w swoje progi grupę najmniej zamożnych, a zazwyczaj najbardziej aktywnych czytelników - młodzież, Książnica - Atlas otworzyła przy swojej warszawskiej księgarni w grudniu 1932 r. wypożyczalnię książek dla młodzieży. ${ }^{182}$

Podobnie korzystne wrażenie wywierało na klientach z pewnością proponowanie im korzystnych warunków kupna książek. Atrakcyjne formy sprzedaży omówiono szczegółowo poniżej; tu chciałabym wspomnieć jedynie o dwóch - bonach książkowych i rachunkach otwartych dla stałych klientów. Bony książkowe, wówczas tzw. czeki-bony wprowadził po raz pierwszy do handlu księgarskiego w okresie międzywojnia J. Mortkowicz. Bony te 
księgarnia wydawała na miejscu lub wysyłała na zamówienie. Kupujący wpłacał na konto PKO równowartość czeku, wypisywał na nim wybrane tytuły i przesyłał czek do księgarni Mortkowicza, skąd wysyłano żądane książki. ${ }^{183}$

Na szerszą skalę metodę tę zastosowała Rada Książki, która na konferencji prasowej 9 XII 1938 r. poinformowała, że wypuszcza bony książkowe (emitowane w porozumieniu z ZKP). Miały one formę artystycznie wykonanych kart z życzeniami, stanowiąc równocześnie podarek w postaci jednej lub kilku książek dowolnej wartości; wartość tę określał kupujący przy nabywaniu bonu. Bon można było realizować w każdej księgarni zrzeszonej w ZKP. Klienci z prowincji mogli przy jego realizacji korzystać z pośrednictwa poczty, najlepiej jednak w tej samej księgarni, która je sprzedała. ${ }^{184}$

Dla stałych klientów udogodnieniem była możliwość posiadania w księgarni rachunku otwartego. Dział rachunków otwartych prowadziła m.in. księgarnia Trzaski, Everta i Michalskiego oraz księgarnia Arctów. Stali klienci - odbiorcy indywidualni, instytucje państwowe i prywatne - posiadając na kontach pewne określone wewnętrzną $\mathrm{i}$ indywidualną umową sumy, co pewien czas uzupełniane kolejnymi wpłatami mogli wejść $w$ posiadanie interesujących ich pozycji przed wpłaceniem całej należności. W ramach działu prowadzono jeszcze jedną formę sprzedaży polegającą na wysyłaniu do przejrzenia stałym klientom określonych wydawnictw. „Przejrzeniówki” przygotowywano dzieląc wedhug indywidualnych zainteresowań i potrzeb książki otrzymywane $z$ frontu, sporządzano listy oferowanych tytułów i przesyłano wraz z nimi poszczególnym odbiorcom. Klienci po wybraniu interesujących ich pozycji, pozostałe zwracali. Otrzymane z powrotem tytuły pracownik konfrontował $\mathrm{z}$ uprzednio sporządzaną listą i wystawiał rachunek płatny na zasadach obowiązujących w dziale. Klientów informowano, że po dziesięciu dniach od dostarczenia towaru rachunek ich zostanie obciążony sumą na którą opiewa lista. Aby jak najbardziej ułatwić tę formę sprzedaży, księgarze posyłali książki przez swoich pracowników, którzy odbierali też zwroty i inkasowali należność. Zasięg działania takiej sprzedaży nie ograniczał się do Warszawy, gdzie korzystało z niej wiele poważnych instytucji. Wysyłano również książki na prowincję m.in. Trzaska, Evert i Michalski wysyłali "przejrzeniówki” do Liceum Krzemienieckiego. ${ }^{185}$

1. atrakcyjne formy sprzedaży,

W omawianym okresie zarówno prenumerata, subskrypcja, sprzedaż ratalna, jak i udzielane rabaty, nie tylko sprzyjały zwiększaniu się liczby 
klientów, wpływając też na wzrost obrotów, ale wręcz warunkowały powodzenie danej oficyny. Powodów tego stanu rzeczy było wiele: mało zamożne społeczeństwo - dla części klientów nabywanie droższych pozycji tą drogą było jedyną możliwością wejścia w ich posiadanie; wysokie koszty, stające się udziałem wydawcy podejmującego edycję dzieł zebranych, pomnikowych, słowników, etc., których część można było pokrywać natychmiast z bieżących wpływów; niewielkie ryzyko popełnienia błędu przy określaniu wysokości nakładu, co w przypadku kosztownych tytułów miało niezwykle istotne znaczenie; zapewniony zbyt na dany tytuł, co daje znaczące korzyści nie tylko wydawcy, ale i księgarzom pośredniczącym w sprzedaży (stały dochód).

a/ subskrypcja,

Przedmiotem subskrypcji były zazwyczaj dzieła wielotomowe, których wydanie planowano na dłuższy okres czasu. Cena danego dzieła w subskrypcji była niższa od późniejszej ceny w wolnej sprzedaży. Subskrypcja była jednak chyba najmniej wówczas popularną z omawianych tu form sprzedaży. Powodem było wydawanie większości droższych edycji w zeszytach, które podlegały sprzedaży w prenumeracie, zakończone zaś wydania sprzedawano na raty. Tym niemniej niektóre oficyny subskrypcje ogłaszały.

W 1931 r. J. Mortkowicz ogłosił subskrypcję z przedpłatą na „Pamiętniki" F. Focha. Cena subskrypcyjna wynosiła 32 zł z egzemplarz oprawny i 24 zł za broszurowany, wpłatę rozłożono na trzy raty. Po zamknięciu subskrypcji cenę podniesiono do odpowiednio do 40 i $30 \mathrm{zł} .{ }^{186} \mathrm{~W}$ tym samym roku rozpisano też subskrypcję na ilustrowane wydanie „Pieśni o Rynku i zaułkach" Or-Ota (80 zł za egzemplarz na papierze czerpanym i 60 zł na bezdrzewnym; w normalnej sprzedaży - 100 i 75 zl).

Subskrypcje stosował także „Rój” na książki droższe; w 1933 r. w ten sposób sprzedawano „Kochanka Lady Chatterley” D. H. Lawrence'a, cena subskrypcyjna wynosiła 10 zł, a katalogowa 15 zł. Rok później rozpisano subskrypcję na książkę R. Thiel'a „W walce ze śmiercią i diabłem” - cena katalogowa 12 zł, w subskrypcji 8 zł. Subskrypcją objęto także w 1936 r. dzieło B. Russell'a „Wiek XIX” w dwóch tomach. Egzemplarze w oprawie broszurowej kosztowały $16 \mathrm{zł}$, a oprawne $20 \mathrm{zł}$. Po ukończeniu subskrypcji ceny te wynosiły 24 i 30 zł. ${ }^{187}$

Tę formę sprzedaży wykorzystywały też: Wydawnictwo J. Przeworskiego, które w 1932 r. ogłosiło subskrypcję na "Księgę z San Michele” A. Munthe, w 1934 r. na „Podróż do kresu nocy” Celine'a, a dwa lata później na jednotomową „Encyklopedię Powszechną”; Gebethner i Wolff - 
w 1934 r. rozpisali subskrypcję na „Pisma” B. Prusa, a w 1937 r. wielką subskrypcję na tanie, ozdobne wydanie „Pism”” E. Orzeszkowej w 30 tomach; IW „Biblioteka Polska”, który w 1939 r. sprzedawał w subskrypcji pierwsze wydanie zebranych pism A. Dygasińskiego oraz „Ksiązka”, która dla realizacji tłumaczenia i wydania „Kapitału” K. Marksa utworzyła specjalny „Fundusz marksowski" i przyjmowała od subskrybentów przedpłaty. ${ }^{188}$

b/ prenumerata,

Prenumerata była wówczas popularniejsza od subskrypcji, ponieważ droższe publikacje często sprzedawano w zeszytach, co sprawiało, iż mogła sobie na nie pozwolić jeszcze większa liczba osób niż przy subskrypcji, dopływ gotówki był częstszy a ewentualna rezygnacja klientów, narażała firmę na stosunkowo mniejsze straty. Prenumerata wnoszona była miesięcznie lub najwyżej kwartalnie (płacono więc częściej, ale sumy mniejsze niż w subskrypcji). Prenumeratę wykorzystywali dla różnych typów swoich publikacji (począwszy od czasopism, poprzez serie, aż do encyklopedii, słowników i wydawnictw pomnikowych) wszyscy więksi wydawcy międzywojnia.

Arctowie sprzedawali tak wydawnictwa wielotomowe, zeszytowe i seryjne. Prenumeratą objęto m.in. zeszytową powieść „Wyspa mędrców” Marii Buyno-Arctowej, „Higienę szkolną” Stanisława Kopczyńskiego, „Prawdy i Herezje. Encyklopedię wierzeń wszystkich ludów i czasów” S. Piekarskiego, „Historię literatury polskiej” J. Krzyżanowskiego, ,Słownik Ilustrowany Języka Polskiego”. ${ }^{189}$ Tą drogą można też było nabywać serie: „Moje Książeczki” i „Zajmujące Czytanki” dla dzieci oraz „Bibliotekę Wielkich Pisarzów”, a w jej ramach np. 8 serii „Powieści Historycznych” J.I. Kraszewskiego ( 30 utworów w 80 tomach) czy 4 serie „Wyboru dzieł” T.T. Jeża ( 17 utworów w 40 tomach). Ceny dla prenumeratorów były korzystniejsze niż w wolnej sprzedaży, a oprócz tego Arctowie stosowali jeszcze dodatkowe warunki ulgowe. ${ }^{190}$

„Rój” oferował w prenumeracie „Biblioteczkę Historyczno-Geograficzną” oraz „Bibliotekę Powieściową”. Początkowo (w latach 1926-1934) była to oferta łączna obejmująca 12 tytułów kwartalnie, $6 \mathrm{z}$,Biblioteczki Historyczno-Geograficznej” i $6 \mathrm{z}$ „Biblioteki Powieściowej”, za 6,95 zł. Można było również zamówić książki z minionego kwartału za tę samą cenę. Okoto 1934 r. w tej samej cenie prenumeratorzy otrzymywali już tylko 9 książek ( 6 z „Biblioteki Powieściowej” i 3 z „Biblioteczki Historyczno-Geograficznej"), a w 1936 r. z powodu zniesienia ryczałtu pocztowego, zmieniono w ogóle warunki prenumeraty wprowadzając tzw. prenumeratę mieszaną, 
obejmującą kwartalnie 7 książek należących do różnych serii wydawniczych (koszt $7 \mathrm{zl}$ ). ${ }^{191}$

Towarzystwo Wydawnicze J. Mortkowicza stosowało prenumeratę przy sprzedaży wydawnictw wielotomowych, zeszytowych i wchodzących w skład serii. Mortkowicz oferował swoje wydawnictwa tą droga już przed I wojną ale na większą skalę rozbudowano tę formę po 1927 r. W prenumeracie można było kupować serie: „Dobre Książki dla Młodzieży” (19271928), „Dzieje Sztuki w Polsce” (1928-1932), „Książnica Współczesnych Pisarzy Polskich" (1930-1934, m.in. zbiorowe wydania pism A. Struga i L. Staffa), „Książnica Wielkich Pisarzy Cudzoziemskich” (w latach 1930-1935 zbiorowe wydanie „Powieści” A. France'a, w 1931 r. „Baśnie” H. Ch. Andersena). Należności rozłożone były na wpłaty tygodniowe, miesięczne lub kwartalne, a w przypadku „Polskiego Malarstwa Współczesnego" (należącego do serii „Dzieje Sztuki w Polsce”) przyjmowano ponadto wpłaty dwutygodniowe, półroczne i roczne. Z kolei drugie wydanie „Pism” Żeromskiego $w$ prenumeracie podzielono na dwie serie: I - powieści (15 tomów, 32 zeszyty) i II - utwory dramatyczne (17 tomów, 20 zeszytów). Oprawny komplet serii I kosztował $110 \mathrm{zł}$, a zeszytowy $80 \mathrm{zk}$, w prenumeracie było to 15 zł miesięcznie za komplet oprawny i 10 zł za zeszytowy. Druga seria była tańsza, komplet oprawny kosztował $75 \mathrm{zł}$ (w prenumeracie $10 \mathrm{zł} \mathrm{mie-}$ sięcznie), a zeszytowy $40 \mathrm{zł}$ ( $6 \mathrm{zł}$ miesięcznie). Ponadto wydawca stosował dodatkowe warunki ulgowe dla prenumeratorów obu serii. ${ }^{192}$ Oprócz serii u Mortkowicza można też było nabywać w prenumeracie pozostałe wydawnictwa wielotomowe, np. „Pisma poetyckie” B. Ostrowskiej czy „Don Kichota" M. Cervantesa. ${ }^{193}$

Z prenumeraty korzystała też na dużą skalę Księgarnia Trzaski, Everta i Michalskiego, której niemal wszystkie wydawnictwa pomnikowe i encyklopedyczne ukazywały się w zeszylach. Pierwszym dziełem sprzedawanym przez TEiM na tych zasadach był wydany w 1925 r. „Słownik angielskopolski" (cena całości 20 zł, zeszyt w prenumeracie 3 zł 50 gr.). Następnie drogą prenumeraty można było m.in. nabywać „Podręczny słownik geograficzny” (1923-1926), „Słownik niemiecko-polski” (1935 r.) ${ }^{194}$, „Wielką Literaturę Powszechną" (1929 r., koszt wynosił 9 zł 50 gr. miesięcznie lub 28 zł 50 gr. kwartalnie) ${ }^{195}$ oraz „Nowy Słownik Języka Polskiego” $(1938 \mathrm{r} .)^{106}$.

Prenumeratę stosowali też: Wydawnictwo J. Przeworskiego, IW „Biblioteka Polska”, która rozprowadzała tak m.in. „Bibljotekę Miłośników Książki”, Krakowska Spółka Wydawnicza przyjmująca prenumeratę np. na „Dzieje kultury polskiej” A. Brücknera, Książnica-Atlas sprzedająca 
tą drogą encyklopedię „Świat i życie” czy serię „Bibljoteka Iskier”, Księgarnia Św. Wojciecha - m.in. „Jasne książki” (wychodziło 12 tomów rocznie, prenumerata wynosiła 2 zł miesięcznie) oraz „Nasza Księgarnia” - m.in. seria „Bibljoteka Dzieł Pedagogicznych”.

\section{c/ sprzedaż ratalna;}

Popularność tej formy sprzedaży spowodowała, iż większość dużych oficyn prowadziła specjalne działy sprzedaży ratalnej, które sprawnie i dokładnie ją realizowały. Na raty można było nabyć niemal każdą publikację, przy czym liczba i wysokość spłat zależały od ceny danego dzieła.

W wydawnictwie Arctów Dział Sprzedaży Ratalnej urządził w 1931 r. Jerzy Arct, zatrudniając w nim ponad dwustu agentów-akwizytorów. Tą formą sprzedaży objęte były przede wszystkim cenne dzieła naukowe, edycje klasyków literatury polskiej, ilustrowane wydawnictwa albumowe, encyklopedie i słowniki. Na raty sprzedawali Arctowie m.in. ,Słownik Ilustrowany Języka Polskiego” (3 tomy), „Słownik frazeologiczny”, ,Słownik wyrazów obcych”, „Słownik ortoepiczny”, „Historię powszechną” (3 tomy), „Dzieje sztuki polskiej”, „Historię literatury polskiej”. Spłaty najczęściej rozłożone były na 19 rat. ${ }^{197}$

Osobny dział ratalny zorganizowany był także u Trzaski, Everta i Michalskiego. Kupno na raty proponowali klientom wydawnictwa akwizytorzy, którzy w imieniu firmy spisywali umowę. Można także było zawrzeć z wydawcą umowę korespondencyjnie, najczęściej za pomocą prospektów, w których oprócz reklam znajdowały się często kupony zamówieniowe. $\mathrm{Na}$ raty sprzedawano te publikacje, których cena wynosiła co najmniej 30 zł, rata wynosiła wówczas 5 zł. ${ }^{198}$ Należność pobierano wraz z kosztami przesyłki po dostarczeniu pierwszych części dzieła, przy czym odbiór książek uznawano za przyjęcie zamówienia i nie mogło być ono już cofnięte. Firma zabezpieczała się przed niesolidnością klientów, informując ich, że w przypadku zalegania z płatnościami należało natychmiast uregulować rachunek za całość wydawnictwa, a także ustalając, iż do momentu ostatniej spłaty książka pozostawała własnością księgarni. Jeżeli upomnienia ze strony firmy nie pomagały, sprawę kierowano na drogę sądową jednak były to przypadki stosunkowo rzadkie. Duże straty z powodu nie wplaconych rat poniosło wydawnictwo dopiero w 1939 r., kiedy to jak wykazały szacunkowe obliczenia utracono kwotę ok. $5.000 .000 \mathrm{zł} \mathrm{-} \mathrm{z} \mathrm{oczywistych}$ powodów pieniędzy nie udało się odzyskać. ${ }^{199}$

Na raty sprzedawał też niektóre swoje tytuły J. Mortkowicz, ale nie zorganizował on osobnego działu i dla każdej takiej sprzedaży warun- 
ki ustalano oddzielnie. W 1928 r. tą metodą sprzedawano ozdobne wydanie „Popiołów” Żeromskiego. Miesięczne raty wynosiły w tym przypadku $1 / 10$ ceny plus $10 \%$ na pokrycie kosztów związanych z ratalną sprzedażą. ${ }^{200}$ W Wydawnictwie J. Przeworskiego utworzono Dział Sprzedaży Ratalnej w 1938 r., więc nie zdążył się on w pełni rozwinąć. ${ }^{201}$ Podobny dział funkcjonował też w IW „Biblioteka Polska”. Również Gebethner i Wolff sprzedawał lą drogą niektóre swoje wydawnictwa m.in. Biblioteczkę Uniwersytetów Ludowych i Młodzieży Szkolnej.

d/ sprzedaż wysyłkowa,

Przekazywanie zamówionych książek hurtowym i indywidualnym klientom poprzez pocztę było często, zwłaszcza w pierwszych latach dwudziestolecia międzywojennego, jedyną możliwością dostarczenia im wybranych tytułów. Rozwijająca się dopiero sieć księgarska, zresztą na niektórych terenach bardzo słaba aż do wybuchu II wojny światowej, nie mogła zaspokoić polrzeb bardziej wymagających klientów. Zamówienia docierały do wydawcy najczęściej dwiema drogami - poprzez ogłoszenia w prasie, których część była jednocześnie kuponami zamówieniowymi oraz poprzez zbierających zamówienia akwizytorów. Czasami rozsyłano także druki adresowe do potencjalnych czytelników (np. określonej profesji) lub korzystając $z$ pośrednictwa poczty przekazywano np. dla danego miasta określoną liczbę druków bezadresowych. ${ }^{202}$

Za pośrednictwem poczty realizowano większość subskrypcji, prenumerat i sprzedaży ratalnych. Wysyłano także tą drogą pojedyncze tytuły. Jedynym problemem, jaki pojawiał się przy tej formie sprzedaży była wysokość opłat poczlowych, które często skutecznie hamowały rozwijanie się sprzedaży wysyłkowej. Zdarzało się, iż przy wydawnictwach tanich czy niewielkich broszurach koszty wysyłki pocztowej potrafiły nawet trzykrotnie przewyższyć wartość publikacji. Średnio przyjąć można, że koszt przesłania książek pocztą wahał się od 15 do $30 \%$ wartości przesyłki. ${ }^{203}$

Sprzedaż wysyłkowa jednak rozwijała się, niektóre firmy miały bardzo rozbudowane działy zajmujące się ekspedycją hurtową i indywidualną. Większość zamówień księgarskich realizowano tą droga, przeważnie za zaliczeniem pocztowym (jeżeli należność regulowana była z góry - przez PKO lub przekazem - stosowano ulgi w opłatach poczlowych ${ }^{204}$ ). Największe i najlepiej zorganizowane wysyłkownie miał Gebethner i Wolff oraz DKP. ${ }^{205}$ Obie firmy korzystały najczęściej z usług poczty lub kolei, choć starały się też rozwijać własny transport samochodowy. Nie ma niestety danych mówiących o procentowym udziale sprzedaży wysyłkowej w całości obrotów firm księgarsko-wydawniczych. 
e/ rabaty i premie,

Rabaty i premie stosowane były przez wydawców w najrozmaitszych okolicznościach i formach. Stosunkowo rzadko stosowano upusty w cenie, natomiast najczęściej wynagradzano kupujących innymi publikacjami lub usługami danej oficyny.

Popularne było nagradzanie premiami prenumeratorów. Wydawnictwo M. Arcta wysyłało bezpłatnie prenumeratorom encyklopedii „Prawdy i herezje” S. Piekarskiego, inną książkę tegoż autora - „Wyznania religijne w Polsce" (przy wysyłce czwartego z dziewięciu zeszytów). ${ }^{206}$ Natomiast nabywcom „Słownika Ilustrowanego Języka Polskiego”, po ukończeniu druku, obiecywali Arctowie wysłać bezpłatnie „ozdobną płócienną oprawę ze złotym wyciskiem”. ${ }^{207}$ „Książka” - współdziałająca z redakcjami czasopism Kultura Robotnicza i Nowa Kultura - zorganizowała w 1923 r. dla prenumeratorów tychże czasopism, sprzedaż swoich książek po znacznie obniżonych (o 50\%) cenach..$^{208}$ Prenumeratorom Tygodnika Ilustrowanego Gebethner i Wolff rozsyłał bezpłatnie, jako dodatek inny swój tygodnik, Przeglad Sportowy. ${ }^{209}$

Prawdziwym specjalistą od przyciągania klientów niezliczonymi nagrodami był jednak w owym czasie „Rój”. Nagrodę można było otrzymać już za sam fakt nabycia całorocznej prenumeraty (np. w 1932 r.). W 1933 r. wszyscy czytelnicy, którzy wykupili prenumeratę na cały rok mieli prawo do kupienia za połowę ceny czterech książek. Rok później ci klienci, którzy wykupili kwartalną prenumeratę i nadesłali ją na tyle szybko, aby zmieścić się w dwustu pierwszych wpłatach, brali udział w losowaniu 10 premii - egzemplarzy książki A. Gide'a „Fałszerze”. Na tych samych zasadach prenumeratorzy roczni mogli zostać posiadaczami jednego kompletu (8 tomów) „Dzieł” F. Dostojewskiego lub jednego z 9 egzemplarzy książki Johna dos Passosa „Manchatan Transfer”. Z kolei pierwszych pięćdziesiąt osób, które zdecydowały się nabyć komplet dzieł F. Dostojewskiego, nagradzano inną książką oprawną w skórę lub dziesięciozłotową premią, polegającą na możliwości wybrania sobie dodatkowych książek na tę właśnie sumę.

Bywało i odwrotnie - nabywcy określonych pozycji mogli zostać nagrodzeni otrzymaniem jednej z prenumerat „Roju”. W wyznaczonych dniach 1933 r. kupując książkę S. Undset „Krystyna córka Lawransa”, T. Dołęgi-Mostowicza „Kariera Nikodema Dyzmy” lub J. Galsworthy'ego „Saga rodu Forsaytów" można było otrzymać jedną z 10 nagród książkowych lub całoroczną czy kwartalną prenumeratę. Na święta Bożego Narodzenia 1934 r. „Rój” przygotował specjalne komplety gwiazdkowe (A - literatura 
społeczno-polityczna, B - powieści, C - „Dzieła” F. Dostojewskiego), których kupno nagradzane było podwójnie. Każdy, kto do 3 lutego 1935 r. nabył jeden z kompletów, otrzymywał bezpłatnie całoroczną prenumeratę „Roju“ (24 tomy „Biblioteki Powieściowej” i 4 tomy „Biblioteczki HistorycznoGeograficznej”), a także miał możliwość uczestniczenia w losowaniu 20 premii książkowych - 1 kompletu „Dzieł” F. Dostojewskiego i 19 egzemplarzy książki Wassermana „Bula Matari”..10

Również Ossolineum premiowało zakupy swoich wydawnictw. W 1936 r. wznowiono "Trylogię" według pełnego tekstu, ustalonego przez Sienkiewicza. Edycja liczyła 26 tomików w cenie 15 zł za całość, ustalono jednak premię: za każde zamówione 12 egzemplarzy jeden dodawano bezpłatnie, natomiast przy zakupie stu egzemplarzy przez instytucje, związki czy stowarzyszenia dodawano dwadzieścia bezpłatnych egzemplarzy. Specjalne listy reklamujące tę ofertę wysyłał Zakład Narodowy do stowarzyszeń, bibliotek szkolnych, organizacji kulturalno-oświatowych, a nawet biskupów poszczególnych diecezji. Na początku 1939 r. Ossolineum wznowiło „Krzyżaków” w taniej edycji, cena kompletu zamiast dotychczasowych 5 zł lub 6 zł 40 gr., wynosiła tylko 3 zł. Każdy setny nabywca tej edycji otrzymywał 10-złotową premię, realizowaną w wydawnictwach firmy (do egzemplarza „Krzyżaków” dołączany był katalog) lub prenumeracie ossolineowskich czasopism. Ponieważ zaś akcja ta odniosła pożądany skutek - w krótkim czasie sprzedano 1.000 egzemplarzy powieści - firma przygotowała w podobnej, taniej edycji „Trylogię”. Najbardziej zainteresowane zakupami okazało się w tym wypadku wojsko, z przedstawicielem którego Ossolineum podpisało umowę na dostarczenie tego dzieła. W umowie zaznaczono, że przy zamówieniach powyżej 10.000 zł wydawnictwo dodawać będzie bezpłatnie $30 \%$ od sumy zamówienia w innych publikacjach własnych. Niestety, planów tych nie udało się już zrealizować. ${ }^{211}$

Mniej spektakularnych rabatów i premii udzielano w codziennej pracy w księgarniach i wydawnictwach. Przykładem może być otrzymywanie rabatu przez posiadaczy rachunku otwartego w księgarni Trzaski, Everta i Michalskiego, udzielano im na kolejne zakupy od 5 do $10 \%$ zniżki. $^{212}$ Był to zresztą dość powszechny zwyczaj, z tym, że walczył z nim ZKP i PTWK, ponieważ na rabaty takie stać było tylko większe księgamie, co odbierało klientów mniejszym placówkom. Powszechnie udzielano także tzw. trzynastek i siódemek (bezpłatny trzynasty lub siódmy egzemplarz ksiażki przy zakupie dwunastu lub sześciu egzemplarzy tego samego tytułu), aczkolwiek tych rabatów udzielali również tylko hurtownicy i wydawcy. ${ }^{213}$ Wyso- 
kie rabaty dostawały na swe zakupy biblioteki, często były one nawet wyższe od tych udzielanych księgarzom - dochodziły nawet do $40 \%$. W ten sposób posiadający własne księgarnie wydawcy i hurtownicy odbierali księgarniom sortymentowym dobrych klientów. ${ }^{214}$

Uregulowanie tych spraw przypadło w udziale Zjednoczeniu Organizacji Księgarskich (ZOK), które wydało regulamin stosunków księgarskich zawierający m.in. podział na kategorie przedsiębiorstw księgarskich i odpowiednie doń wysokości normalnych rabatów udzielane im przez wydawców. Ustalono też rabaty, jakich wolno było udzielać publiczności, np. każdemu nabywcy większej ilości książek na rachunek gotówkowy, zależnie od wartości rachunku przysługiwała 5-20\% zniżka, a wypożyczalnie i czytelnie zarobkowe mogły kupować książki z 20\% rabatem od ceny katalogowej, ale tylko wówczas, gdy zarejestrowały się w Biurze Rejestrowym i Kredytowym ZOK i opłaciły roczne składki. ${ }^{215}$

f/ wyprzedaże, obniżki i zmiany cen,

Osobnym zagadnieniem są popularne w owym czasie wyprzedaże, noszące nazwę „tanich tygodni”. Potrzeba pozbywania się zalegających na składach tytułów wydawała się oczywista, natomiast liczne kontrowersje i dyskusje budziła forma przeprowadzania wyprzedaży (chodziło o straty ponoszone przez sortymentystów). Nie trzeba dodawać, że „tanie tygodnie" cieszyły się ogromnym powodzeniem wśród czytającej publiczności. Wyprzedaże organizowały z mniejszą lub większą częstotliwością niemal wszystkie firmy.

W połowie lat dwudziestych tzw. tanie tygodnie wyprzedaży, również wysyłkowej wprowadził w rodzinnej księgarni Zygmunt Arct. Pierwsza taka wyprzedaż odbyła się w dniach 28 lutego - 7 marca 1925 r. ${ }^{216}$. Po jej zakończeniu książki wracały do dawnej wartości. Córka Stanisława Arcta wspomina, iż „Tygodnie te cieszyty się wielkim powodzeniem. W księgarni na Nowym Świecie tloczono się glowa przy glowie jak po paczki u Bliklego w thusty czwartek." 217 . Ponadto Stanisław Arct uruchomił także nowy, specjalny dział książek i nut po cenach obniżonych pod nazwą „Tani bazar”218, który w przeciwieństwie do „tanich tygodni” miał charakter stały. Arctowie organizowali też obniżki cen książek z poszczególnych dziedzin, np. w 1929 r. ogłoszono dwumiesięczną obniżkę o 50\% większości cen książek radiofonicznych. ${ }^{219}$

Niemal regułą było obniżanie cen książek przez „Rój”, kiedy tylko wycofano całość lub znaczną część kapitału włożonego w wydanie książki. Obniżki te miewały nierzadko charakter drastyczny, wywołując protesty 
sortymentystów i wprowadzając chaos na rynku księgarskim. Na ogół raz do roku wszystkie książki „Roju” można było nabyć za pół ceny i była to świadoma polityka firmy stosującej zasadę szybkiego obrotu. Za bezcen sprzedawano końcówki nakładu, organizowano też wyprzedaże sezonowe, np. gwiazdkowe. Przy wszystkich jednak wyprzedażach ceny obniżano tylko w określonym czasie, po czym książki wracały do pierwotnej wartości. ${ }^{20}$

Podobną politykę sprzedażową - natychmiastowe obniżanie cen po wycofaniu większości kosztów - stosowało Wydawnictwo J. Przeworskiego. Wyprzedaże poprzedzone były intensywną propagandą za pomocą katalogów, ogłoszeń, prospektów, zawiadomień o obniżce ceny książek, aby zachęcić klientów do zakupów. Kilkakrotnie firma brała też udział w tzw. „Tygodniu taniej książki”, który został po raz pierwszy ogłoszony przez Związek Księgarzy Polskich w 1925 r., a następne, po przerwie w 1930 r., organizowano pod zmienioną nieco nazwą „Tani tydzień książki”. ${ }^{221}$ Wyprzedaże urządzaty też inne firmy, sądząc po zachowanych drukach reklamowych: DKP ${ }^{222}$, IW „Biblioteka Polska”, ,Nasza Księgarnia”, PWKS, Wydawnictwo J. Mortkowicza i Gebethnera i Wolffa.

Większość z tych firm brała też udział we wspomnianych już „Tygodniach Taniej Książki” pod patronatem ZKP. Zazwyczaj odbywały się one w lutym, aby ożywić ten słaby zazwyczaj okres handlowy. Przygotowania przeprowadzano odpowiednio wcześniej. Wydawcy zawiadamiali księgarzy o zamierzonych obniżkach, zaopatrywali ich w książki, wspólnie i indywidualnie prowadzono intensywną akcję reklamową. Ukazywały się ogłoszenia w prasie, lokale księgarń przygotowywano do spodziewanego napływu klientów. Rozsyłano setki tysięcy egzemplarzy katalogów i prospektów. Nadchodziło tyle zamówień, że niemożliwe było zrealizowanie ich w ciagu tygodnia, mimo zatrudniania dodatkowego personelu. Właściwie mimo nazwy „tydzień" z reguły okres ten przedłużał się, nawet do miesiąca. ${ }^{223}$

W drugiej połowie lat trzydziestych ZKP przystapił do regulacji kwestii obniżek cen i przeprowadzania wyprzedaży. Przyjęte przepisy chronić miały przede wszystkim księgarzy - sortymentystów. Ustalono, iż „cena ksiażki może ulec zmianie nie wcześniej niż po trzech latach od ukazania się $z$ druku. (...) O obniżeniu ceny ksiażek wydawca obowiqzany jest oglosić w Przeglaqdzie Księgarskim najpóźniej na miesiąc przed terminem, w jakim obniżenie tej ceny nastapi." Zjazd ZKP obradujący w Poznaniu w maju 1937 r. stwierdził ponadto, że „opierając się na doświadczeniach imprez wyprzedażowych, w formie tanich tygodni w latach do 1936 r. i ostatniej pod hasłem ,propagandowe dwa tygodnie taniej książki”, można ocenić, iż imprezy 
te są szkodliwe dla warunków normalizowania się prawidłowego zbytu książki o cenie stałej i książki ukazującej się na rynku jako nowość. Uchwalono zatem przeciwstawiać się na przyszłość wszelkim poczynaniom wyprzedażowym i nie brać w nich udziału (cały czas mowa o księgarstwie sortymentowym). Zalegające tytuły proponowano sprzedawać w normalnym trybie, jako książki o cenach zmienionych. ${ }^{224}$

Dodać można, iż czasami w celach reklamowych stosowano pozornie paradoksalnie zabieg odwrotny od zniżek - informowano mianowicie o podwyższeniu ceny określonego dzieła. Jednocześnie jednak obwieszczano, iż wyższa cena obowiązywać będzie od danego dnia, a do tego terminu książkę kupować można po starej cenie. ${ }^{225}$

2. przekazywanie gratisów dla bibliotek, fundowanie książek na nagrody i dary charytatywne,

Stosunek polskiego księgarstwa do ofiarowywania książek na szlachetne cele był zaskakująco ambiwalentny. $Z$ jednej strony darów takich oczekiwali sami księgarze chociażby kompletując bibliotekę Związku Polskich Pracowników Księgarskich; w Księgarzu publikowano wówczas (lata 1925-1926) dość kąśliwe uwagi o braku chętnych ofiarodawców i skrupulatnie wyliczano podziękowania dla tych, którzy książki przesyłali - głównie Gebethnera i Wolffa. ${ }^{226} \mathrm{Z}$ drugiej zaś strony potrafiono opublikować tak kuriozalny tekst jak komunikat z 1929 r. umieszczony w Przegladzie Księgarskim pt. Żebranina książkowa: , Otrzymaliśmy wiadomość, że do kilku firm wplynęty prośby o bezplatne ofiarowanie ksiażek dla bibljotek. Przypominamy, że Biuro ZKP posiada i ekspediuje na żqdanie schemat odpowiedzi na podobne prośby. Tekst odpowiedzi wzmiankowanej byl ogloszony w „P [rzegladzie] K[sięgarskim]” $n r 26 z$ dn. 26 VI 1928 str. 410 "227. Zdumiewająca wydaje się ta zwarta i solidarna obrona, przed proszącymi o wsparcie swych inicjatyw organizatorami bibliotek i propagatorami kultury i czytelnictwa.

Publikacja takich tekstów nie przeszkadzała księgarzom pochwalać ewentualnych ofiarodawców, a samym darczyńcom chlubić się darami. W tym samym bowiem 1929 r. w tymże Przeglądzie Księgarskim opublikowano artykuł informujący, iż ,Z okazji 350-lecia istnienia Uniwersytetu Stefana Batorego $w$ Wilnie firmy zrzeszone w wileńskim kole ZKP ofiarowaty uniwersytetowi szereg wartościonych wielotomowych dziel oprawnych w pólskórek”. Były wśród nich m.in. Oddział Wileński PTKK „Ruch”, Księgarnia Józefa Zawadzkiego oraz Gebethner i Wolff. ${ }^{228}$ Do artykułu dołączono fotografię darów. 
W 1938 r. szczególne emocje wywołało w Polsce przyłączenie do Rzeczpospolitej Zaolzia. W patriotycznym geście ofiarowywano zatem polskie książki dla zaolziańskich szkół i bibliotek. Zakład Narodowy im. Ossolińskich we Lwowie ofiarował na ręce Kuratora Śląskiego Okręgu Szkolnego 1.649 egzemplarzy podręczników dla uczniów szkół gimnazjalnych, 2.880 egzemplarzy podręczników dla szkół powszechnych i 240 egzemplarzy lektur uzupełniających. PWKS przyznało zaś do dyspozycji wojewody śląskiego 40.150 bezpłatnych egzemplarzy podręczników, książek i pomocy naukowych dla szkół powszechnych. ${ }^{229}$

Hojnym darczyńcą było Wydawnictwo J. Przeworskiego, które w latach 1937-1939 ofiarowywało książki „pod choinkę” na imprezach urządzanych przez Związek Pracowników Książki. Firma podarowała też w 1937 r. książki dla organizowanej wówczas Czytelni Dla Młodzieży przy Bibliotece Publicznej m.st. Warszawy, a w 1939 r. przekazała ksiązki do Biblioteki Oddziału Poznańskiego Związku Zawodowego Pracowników Książki. ${ }^{230}$

Rozdawnictwo książek na naprawdę dużą skalę, praktykował Zakład Narodowy im. Ossolińskich. Począwszy od 1919 r. wydawnictwo przesyłało książki do bibliotek uniwersyteckich, szkolnych, ludowych, bibliotek stowarzyszeń i kół naukowych. Spośród naprawdę wielkiej liczby obdarowanych wymienić należy: Bibliotekę Uniwersytetu im. Stefana Batorego w Wilnie, Oddział Łódzki Warszawskiego Towarzystwa Prawniczego, bibliotekę Seminarium Polonistycznego Uniwersytetu Warszawskiego, Czytelnię Akademicką we Lwowie, Koło Historyków Studentów Uniwersytetu Poznańskiego, Koło Medyków Uniwersytetu Warszawskiego, bibliotekę Seminarium Historii Literatury Wolnej Wszechnicy Polskiej w Warszawie, Bibliotekę Miejską w Siedlcach, Miejską Bibliotekę Publiczną w Białymstoku, Bibliotekę Państwowej Szkoły Morskiej w Gdyni, Bibliotekę Pracowników Kolejowych im. Henryka Sienkiewicza w Gdańsku, Bibliotekę Statku Szkolnego „Dar Pomorza” i wiele innych. ${ }^{231}$

Jeżeli książek nie można było ofiarować to chwalono się chociaż ich popularnością i obniżeniem cen, tak jak Gebethner i Wolff, który w $1938 \mathrm{r}$. in formował: "Spośród 150 ksiażek wybranych przez Poradnię Bibliotecznq jako księgozbiór zasadniczy biblioteki wiejskiej znajduje się 36 tomów Gebethnera i Wolffa. Ceny na te ksiqżki zostały obniżone, tak że koszt calego księgozbioru ulegl zmniejszeniu." 232 Poniżej opublikowano kompletna listę z cenami tychże publikacji. 
Księgarstwo polskie starało się także propagować ofiarowywanie książek na nagrody, głównie tzw. nagrody pilności. ${ }^{233} \mathrm{~W}$ propagandzie tej chodziło o zainteresowanie rodziców i instytucji podobnymi akcjami, które dostarczyłyby pożytecznej lektury młodzieży podnosząc jednocześnie obroty księgarń. Nierzadko się to udawało, jak np. w 1937 r. kiedy to Zarząd m.st. Warszawy ofiarował w upominku dla najlepszych absolwentów szkół miejskich 20.000 egzemplarzy książek. ${ }^{234}$ Aby akcje takie ułatwiać wielu wydawców publikowało specjalne katalogi z książkami na nagrody czy podarki. Zachowały się takie katalogi Wydawnictwa M. Arcta i Gebethnera i Wolffa. Jedynym wydawnictwem o którym wiadomo na pewno, iż fundowało książki na nagrody było nieocenione Ossolineum, przekazujące swoje wydawnictwa m.in. jako nagrody w konkursach. ${ }^{235}$

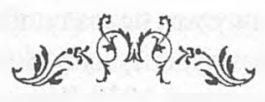

\section{Przypisy:}

T. Hussak: Reklama i propaganda ksiqżki. Część I, Warszawa 1969, s. 127.

${ }^{2}$ Aida - media 1994, nr 2, str. 20.

${ }^{3}$ Por. S. Z. Zakrzewski: Reklama: cele - środki - rodzaje. Warszawa 1942 oraz S. Z. Zakrzewski: Poradnik stosowania reklamy. Warszawa 1937.

${ }^{4}$ Olgierd Langer był jednym z najwybitniejszych polskich specjalistów w dziedzinie reklamy w okresie dwudziestolecia międzywojennego. Doskonale rozumiał zmiany, które nastapiły w metodach sprzedaży od czasu rozwinięcia masowej produkcji i konsumpcji: „Sprzedaż, która pierwotnie uważano za czynność zupelnie prosta, polegajaca na wymianie pieniędzy za towar, przeistoczyla się w zlożony proces psychologiczny. Zrozumiano, że sprzedaż, lub lepiej mówią, kupno uskutecznia się w umyśle kupujacego, ze zaplata za towar jest tylko ostainia faza procesu psychologicznego, jakkolwiek najbardziej widocznq dla sprzedajqcego i nawet najwyraźniejsza dla kupujqcego. Kupujacy musi przedtem dowiedzieć się o istnieniu pewnego rodzaju towaru, nabrać przekonania, ze towar odda mu w rzeczywistości pewne korzyści, upewnić się o jego wartości i dopiero potern wszystkim zdecydować się na jego kupno. Dlatego też , sprzedawać” znaczy to wywolać w umyśle drugiej osoby za pomocq rozmaitych sposobów (mowy, druku, rysunku) pewien ściśle określony proces psychologiczny, który ma doprowadzić w kańcu do czymu kupienia towaru." O. Langer: Zasady oglaszania, Warszawa 1927, s. 25.

${ }^{5}$ Tylko takie firmy było stać na podejmowanie dużych akcji reklamowych i stosowanie wielu metod reklamy, a jednocześnie tylko reklamowanie tytułów o dużych nakładach było najbardziej opłacalne i efektywne. Co prawda wpedzało to małe firmy w znany schemat „Zaklętego koła” - „Nie reklamujemy się ponieważ nie mamy pieniędzy. Nie mamy pieniędzy, bo interes się nie kręci" - ponieważ się nie reklamujemy (zob. I. Rabiej: Reklamodawcy dziesięć grzechów glównych, Aida-media $1994 \mathrm{nr} 6$ s. 20), ale nie zmieniało to faktu, że drobne wydawnictwa istotnie raczej się nie reklamowały. 
"W tym samym okresie w prasie amerykańskiej czy niemieckiej stosunek ten wynosił od 30 do $50 \%$. M. Brzostowski: Reklama prasowa, Warszawa 1976, s. 52-53.

${ }^{7}$ Tamże.

${ }^{8}$ Wszystkie poniższe wnioski oparte zostały na przeglądzie następujących periodyków: Expressu Porannego, Kurjera Poramego, Kurjera Czerwonego i Dobrego Wieczoru (dzienniki warszawskie), Ilustrowanego Kurjera Codziennego (dziennik krakowski), Wiadomości Literackich, Tygodnika Ilustrowanego, Swiata, Kina (tygodniki), Morza (miesięcznik), Plomyka (tygodnik dla dzieci).

9 Ze względu na ogrom materiahu źródłowego nie sposób jest dokonać przeglądu wszystkich dzienników i czasopism z lat 1918-1939. Na podstawie analizy danych statystycznych dotyczących rynku książki w omawianym okresie, zdecydowano się skoncentrować na prasie $z$ lat 1929 i 1938. Przy ustalaniu zakresu chronologicznego wykorzystano dane z roczników statystycznych oraz obliczenia M. Czarnowskiej, N. Kraśko i J. Kosteckiego. Z wyliczeń przeprowadzonych przez tychże autorów wynika, że właśnie lata 1929 i 1938 cechują się najwyższą produkcją wydawniczą w okresie dwudziestolecia międzywojennego (w swoich dziesięcioleciach), tzn. najwyższą liczbą tytułów i nakładów globalnych zarazem. Przyjęto, że właśnie lata największej prosperity były okresem najszerzej stosowanych działań reklamowych. Maly rocznik statystyczny 1930, Warszawa 1930; Maly rocznik statystyczny 1938, Warszawa 1938; M. Czamowska: Ilościowy rozwój polskiego ruchu wydawniczego w latach 1501-1965, Warszawa 1967, s. 79-80, 170; N. Kraśko: Produkcja druków nieperiodycznvch w II Rzeczypospolitej w latach 1924-38. [W:] Instytucje - publiczność - sytuacje lektury. T. 4 pod red. J. Kosteckiego, Warszawa 1992, s. 254-255, 294-297; J. Kostecki: Ruch wydawniczy na ziemiach polskich (1877-1986). Tamże, s. 153-224.

${ }^{10}$ Wiadomości Literackie 1929, nr 1-52

"Świat 1938, nr 1-52

${ }^{12}$ Tygodnik Ilustrowany $1929 \mathrm{nr} 1-52 ; 1938 \mathrm{nr} 1-52$

${ }^{13}$ Dane z drugiej połowy lat trzydziestych. J. Łojek, J, Myśliński, W. Władyka: Dzieje prasy polskiej, Warszawa 1988, s. 117

${ }^{14}$ Kino osiagało 60.000 egz. nakładu i mimo konkurencji (np. Ekranu, Filmu czy Kinematografiu Polskiego) obejmowało swoim zasięgiem cały kraj A. Zawada: Dwudziestolecie literackie, Wrocław 1997, s. 144

${ }^{15}$ Kino 1930, nr 16, s. 11; nr 17, s. 15; nr 30, s. 15

${ }^{16}$ Kino 1930, nr 18, s. 6

${ }^{17}$ Szacowano, że pod koniec lat dwudziestych liczba prenumeratorów Plomyka i Plomyczka wynosiła przeszło 60.000 osób, z czego jednak znaczna część nabywana była przez szkoły i klasy, co dawać miało około miliona młodych czytelników. W 1934 r. sam Plomyk miał 50.000 prenumeratorów. „Nasza Księgamia”. 40 lat dzialalności dla szkoly i dziecka, Warszawa 1961, s. 34-36; J. Łojek, op. cit., s. 119

${ }^{18}$ Plomyk 1929/1930, nr 2, s. 42; nr 16/17, s. 386; nr 31, s. 727; nr 41, s. 961; Plomyk 1938/1939, nr 2, s. 517 ; nr 29/30, s. 670

${ }^{19}$ Znamienny jest tu przykład Tygodnika llustrowanego, którego wydawcą w latach 18821932 pozostawał Gebethner i Wolff. Z rozgoryczeniem pisał na ten temat wieloletni pracownik redakcji Tygodnika Stanisław Lam: ,Firma Gebethnera i Wolffa (...) chciala mieć w tym piśmie organ reklamowy swoich wydawnictw, co znów pociagalo za sobq calq politykę wobec innych nakładców i autorów, stojacych poza orbitq Gebethnerowską. (...) Tym gorzej jeszcze, że Gebethner i Wolff poza księgarstwem bawil się w krytykę literackq i chcial po- 
gląd swój narzucać opinii ogólu. Najnowsza poezja na przyklad nie cieszyla się jego uznaniem. Czy można bylo jednak pomijać to zjawisko, zamknqć oczy na mlode talenty, ignorować Tuwima, Wierzyńskiego i Slonimskiego, nie wspominać o Skamandrze? (...) Kiedy raz ochważtem się w tekście rozpocząć cykl artykulów o najnowszej poezji, z portretami mtodych pisarzy - po drugim felietonie otrzymalem telefon od pani Anny Wolffowej, n'vstepujacej zapewne dla , delikatności” w imieniu firmy z zapytaniem: „Czy duzo jeszcze będzie pan pisać o tuch Slonimskich?" "Aby pani ,Tygodnika" nie profanować-odpowiedzialem - przerywam dalszy druk artykulów". (...) A Gustaw Wolff nawet krzywil się na notatki podające treść nowych zeszytów ,Skamandra”. Pewnie, ze ta poezja nie byla w jego smaku. "Profanus" (takim bowiem pseudonimem podpisywal pan Gustaw swoje , utwory" i przeklady Heinego oraz rosyjskich poetów) rymowal sposobem częstochowskim, a asonanse i Slopiewnic Tuwimowskie to bylo dla niego homendzım." S. Lam: Życie w'śród wielu, Warszawa 1968, s. 286-287.

${ }^{20}$ Poniższe wnioski sformułowano na podstawie lektury następujących periodyków: Ksiqżki (1922), Księgarza (1919-), Kurjera Ksiegarskiego (1926-), Przeglądu Bibljograficznego Gebethnera i Wolffa (1905-), Przegladu Księgarskiego (1918-), Przegladu Literackiego (1930-), Świata Ksiqżi (1928-), Wiadomości Ksiegarskich (1930-), Wiadomości Wydawniczych PTWK (1936-).

${ }^{21}$ J. Mucharski: Ksiązka od M. Arcta. Księgarnia Nowy Świat 35, $52 \times 36 \mathrm{~cm}$

${ }^{22}$ M. Wisznicki: Prenumerujcie! Czytajcie! „Tygodnik Ilustrowany” 1859-1927, $104,5 \times 71,5 \mathrm{~cm}$

${ }^{23}$ Kilkanaście plakatów z omawianego okresu posiada jedynie Muzeum Plakatu w Wilanowie, w większości jednak dotyczą one reklamy prasowej. Muzeum posiada także plakat reklamujący - bez nazwy wydawcy - serię: „Biblioteka Groszowa” (autor nieznany: Pamiętaj ten znak „Biblioteka Groszowa” 1918-1924, 71x53 cm).

${ }^{24}$ W latach trzydziestych Gebethner i Wolff dołączal gratis (do ekspedycji piątkowej) wszystkim klientom swojej hurtowni plakaty, reklamujące ostatnie nowości bieżącego tygodnia, w celu umieszczenia ich w widocznych miejscach lub wręcz w witrynach. Wiadomości Ksiegarskie 1931, nr 6, s. 3.

${ }^{25}$ Przeglad Ksiegarski 1929, nr 9, s. 175.

${ }^{26}$ Przeglad Ksiegarski 1937, nr 22, s. 224.

${ }^{27}$ A. Zawada, op. cit., s. 132 (fot.).

${ }^{28} \mathrm{~W}$ grudniu $1930 \mathrm{r}$. Gebethner i Wolff zainstalował co prawda reflektory w celach reklamowych, ale oświetlały one całą wieżę gmachu przy ul. Zgoda 12 (siedziba firmy). K. Konarska: Czasopisma i katalogi furmy Gebethner i Wolff, Warszawa 1966, s. 38-39 (praca magisterska).

${ }^{29}$ S. Arct: Okruchy' wspomnien, Warszawa 1962, s. 573.

${ }^{30}$ Fotografia z: Katalog wydawnictw szkolnych, Gebethner i Wolff, Warszawa 1923.

${ }^{31}$ Z. Paliszewski: Dzialalność księgarska firmy Trzaska, Evert i Michalski w latach 19201939, Warszawa 1984, fot. 27 (praca magisterska).

32 Tamże, fot. 26-27.

${ }^{33}$ Fotografia z prospektu: Gebethner i Wolff, Dzial komisowo-hurtowy. Warszawa [ok. 1931].

${ }^{34}$ T. Hussak, op. cit., s. 99.

${ }^{35}$ Współczesne polskie drukarstwo i grafika ksiqziki. Wrocław 1982, s. 320.

${ }^{36}$ Slownik pracowników ksiqżki polskiej, s. 826. 
${ }^{37}$ M. Mlekicka: Jakub Mortkowicz - ksiegarz $i$ wydaw'ca, Wrocław 1974, s. 197.

${ }^{38}$ H. Mortkowicz-Olczakowa: Podznakiem kloska, Warszawa 1962, s. 101-104.

${ }^{39}$ Oto np. propozycje na lipiec 1929r.: 3.VII. * J.P. Woronicz 1757, 4.VII. Święto narodowe Stanów Zjednoczonych A.P., Ogłoszenie niepodległości 1776, 6.VII. Spalenie Jana Husa 1415, 7.VII. Utworzenie Księstwa Warszawskiego 1807, 9.VII. (K. Libelt 1875, 14.VII. Święto narodowe Francji. Wzięcie Bastylji 1789, 15.VII. (A. Fredro 1876. Bitwa pod Grunwaldem 1410, 17.VII. Utworzenie Komisji Edukacyjnej 1773, 19.VII. (T. Zan I855, 28.VII. (Wł.L. Anczyc 1883. * J.I. Kraszewski 1812. * Sewer (S. Maciejowski) 1839, 29.VII. (J. Lelewel 1861. Przeglad Księgarski 1929, nr 25/26, s. 390-391.

40 Przegląd Ksiegarski 1929, nr 52, s. 825.

${ }^{4 !}$ Własne sklepy firmowe posiadały następujące firmy: Gebethner i Wolff, M. Arct, Zakład Narodowy im. Ossolińskich, E. Wende i S-ka, Spółdzielnia Księgarska „Książka”, Wydawnictwo J. Przeworskiego, Księgarnia Ferdynanda Hoesicka, Księgamia J. Zawadzkiego, Trzaska, Evert i Michalski, Towarzystwo Wydawnicze J. Mortkowicza, PTKK „Ruch”, IW „Biblioteka Polska”. Salon miał Dom Ksiażki Polskiej.

${ }^{42}$ E. Zawadzka: Dzialalność księgarska firmy Arcta w Warszawie w latach 1887-1950, Warszawa 1984, s. 143 (praca magisterska).

${ }^{43}$ Są to wspomnienia Anny Rudowskiej, córki Stanisława Arcta opublikowane we fragmentach w artykule A. Bogdańskiego: Ocalić od zapomnienia. Księgarz 1978, nr 1, s. 48-54.

4 M. Kurzyna: Wankkowicz, Warszawa 1972, s. 28.

${ }^{45}$ Kurier Polski 1932, nr 131, cyt. za : M. Trzcińska: Książnica Allas w'Warszawie 19241939, Warszawa 1969, s. 67 (praca magisterska).

*6 Przeglad Ksiegarski 1929, nr 52, s. 824.

${ }^{47}$ W 1937r. gdy Gebethner i Wolff wydał „Szatana z 7-ej klasy” K. Makuszyńskiego, zastosował zupełnie nowy na polskim gruncie pomysł reklamowy. Mianowicie dostarczył księgarniom sortymentowym, które sprzedawały ten tytuł, wielką tekturową księgę, będąca atrapa powieści, do wystawienia w witrynach. Przegląd Księgarski 1937, nr 24, s. 260.

${ }^{48}$ Wyniki ogłoszono w dwóch grupach - księgarnie warszawskie i zamiejscowe: pierwszego miejsca w stolicy nie przyznano, drugie równorzędne zajęły: Księgarnia „Naszej Księgarni" i Księgarnia H. Wirgin; poza Warszawą wygrała Księgarnia Polska, Józef Kohlman, Ostrów Wlkp. Księgarz 1938, nr 5, s. 82.

${ }^{49}$ M. Trzcińska, op. cit., s. 68.

519 Przegląd Księgarski 1929, s. 247.

${ }^{51}$ Konkurs „Wystaw Okiennych Księgarskich” zorganizował w grudniu 1937 r. Oddział Związku Zawodowego Pracowników Księgarskich w Wilnie w porozumieniu z Delegatem Zarządu Głównego ZKP na Okręg Wileński. Przegląd Księgarski 1938, nr 1-2, s. 13.

${ }^{52}$ Księgarz 1925, nr 4, s. 2.

${ }^{53}$ Konkurs zorganizowano z okazji III-go Kursu Przeszkolenia dla Księgarzy Sortymentystów. Przegląd Księgarski 1938, nr 13-14, s. 149.

${ }^{54}$ Przeglad Ksiegarski 1929, nr 52, s. 824.

${ }_{55} \mathrm{~W}$ podobnych konkursach brały też udział i zdobywały nagrody firmy: Księgarnia J. Przeworskiego i Księgarnia Ossolineum. B. Dybicz: Księgarnia i wydawnictwo Jakuba i Marka Przeworskich w latach 1901-1939, Warszawa 1992, s. 91 (praca magisterska); Przegląd Ksiegarski 1929, nr 2, s.28

${ }^{56}$ E. Paruszewska-C wikiel: Ksiegarstwo wileńskie w okresie międzywojennym, Warszawa 1983, s. 83 (praca magisterska); K. Dolindowska: „,Ksiqżka” i , Tom”. Z dziejów legalnych 
wydawnictw KPP, Warszawa 1977, s. 23. M. Mlekicka: Jakub Mortkowicz..., Wrocław 1974 , s. 48.

${ }^{57}$ Opis powyższy wynika z zachowanych fotografii. Tak wyglądały np. księgamie IW „Biblioteka Polska”, Wydawnictwa Trzaski, Everta i Michalskiego, warszawskie i pozostałe lokale Gebethnera i Wolffa, Księgamia M. Arcta. Zdjęcia pochodzą z: Katalog dziel nakladowych $i$ komisowych, Warszawa IW .,Biblioteka Polska”, 1930; Księgarnia Trzaski. Everta i Michalskiego 1927. [katalog], Warszawa 1927; Katalog wyclawnictw szkolnych, Warszawa Gebethner i Wolff, 1923; E. Zawadzka, op. cit., il. 22 i 23.

${ }^{5 R}$ Niewiele okien miały małe księgarnie jak np. lokal Spółdzielni Księgarskiej „Książka", mieszczący się przy ul. Kruczej 26 róg Hożej (wejście od Hożej), który posiadał jedną witrynę, ale także placówka M. Arcta mieszcząca się w kamienicy Hołowczyca na Nowym Świecie 35, która wyposażona była jedynie w dwa okna, księgarnia firmy TEiM przy Krakowskim Przedmieściu 13 (Hotel Europejski), która miała jedną witrynę czy Księgarnia J. Mortkowicza na ul. Mazowieckiej 12, posiadająca dwa okna wystawowe. K. Dolindowska, op. cit., s. 23; S. Arct, op. cit., s. 573 (fot.); M. Pieczonka: Ksiegarnia Wydawnicza Trzaska, Evert i Michalski, Kraków 1993, s. 155; M. Mlekicka: Jakub Mortkowicz...., Wrocław 1974, s. 48.

5y Zdjęcia na okładce prospektu: Jak powstaje ksiazzka Wydawnictwa M. Arcta. Warsżawa [ok. 1929].

${ }^{61)}$ H. Mortkowicz-Olczakowa, op. cit., s. 62.

${ }^{61}$ E. Zawadzka,op. cit., s. 143.

${ }^{62}$ M. Pieczonka, op. cit., s. 155; E. Zawadzka, op. cit., s. 109.

${ }^{63}$ Lady takie stały w księgamiach Gebethnera i Wolffa - krakowskiej i łódzkiej. Patrz przypis 57.

${ }^{64}$ Interesującą ekspozycję tego typu widać na zdjęciu lokalu IW „Biblioteka Polska”. Pośrodku księgami, przy kolumnie, ustawiono niewielki stolik, obity ciemnym suknem z jasnym napisem poniżej blatu: „Wielka Bibljoteka - nowe wydanie”. Na stoliku umieszczono ksiąziki. Patrz przypis 44.

${ }^{65}$ M. Pieczonka, op. cit., s. 155.

${ }^{66}$ Z. Paliszewski, op. cit., s. 59

${ }^{67}$ Encyklopedia wiedzy o ksiaże, Warszawa 1971, s. 1014; Katalog dziel nakladowych i komisowych, Warszawa IW „Biblioteka Polska”, 1930; Katalog wydawnictw IW „Biblioteka Polska". Warszawa maj 1926, s. 4.

${ }^{68}$ Kurjer Księgarski 1936, nr 18, s. 4; nr 21, s. 4.

${ }^{69}$ J. Muszkowski: Dom Ksiażki Polskiej, Warszawa 1922, s. 28.

${ }^{70}$ M. Mlekicka: Jakub Mortkowicz..., s. 53-56; H. Mortkowicz-Olczakowa, op. cit., s. 57.

${ }^{71}$ H. Mortkowicz-Olczakowa, op. cit., s. 142.

${ }^{72}$ J. Okopień: Międzywojenni uydawcy: Gebethner i Wolff, Widawca 1995, nr 3, s. 31.

${ }^{73}$ W latach 1928-1934 istniały przy Wolnej Wszechnicy Polskiej - Studium Księgarskie Wydziału Pedagogicznego (tu organizowano dwuletnie Kursy Księgarskie) oraz Wyższe Studium Księgarskie. Nie miały one jednak charakteru masowego (kursy ukończyło 32 słuchaczy, natomiast Studium wydało zaledwie 1 dyplom) i funkcjonowały zaledwie 6 lat, a znakomita większość księgarzy uczyła się zawodu podejmując pracę w księgarni. Encyklopedia wiedzv o ksiqżce, s. 1353.

${ }^{74}$ Tamże. Wg Z. Arcta kursy zorganizowano z inicjatywy Gebethnera i Wolffa. Z. Arct: 
Gawędy o księgarzach, Wrocław 1972, s. 33.

${ }^{75}$ S. Dippel: O księgarzach, którzy przeminęli, Wrocław 1976, s. 124.

${ }^{76}$ Encyklopedia wiedzy o ksiażce, s.1353 ; S. Dippel: op. cit., s. 124.

${ }^{7}$ S. Arct, op. cit., s. 491-492.

${ }^{78}$ S. Arct, op. cit, s. 235-240 ; Z. Arct, op. cit., s. 82-109.

${ }^{79}$ Obecnie rola okładki wydaje się być większa, gdyż wchodząc do księgarni klient najczęściej staje sam wobec ogromu tytułów, i jeżeli nie jest wyrobionym czytelnikiem, to właśnie okładka może wpłynąć decydująco na podjęcie decyzji o zakupie. W okresie międzywojnia znakomita większość księgarń mieściła się w małych lokalach i książki z konieczności stały na półkach grzbietem do klienta. Okładka nie była więc pierwszą rzeczą, na która padał wzrok kupującego. Ponadto istotniejsza była funkcja sprzedającego, w znakomitej większości przypadków to właśnie księgarz doradzał lub odradzał nabycie danego tytułu.

${ }^{80}$ B. Dybicz: op. cit., s. 77

${ }^{81}$ M. Mlekicka: Wydawnictwo Jakuba Mortkowicza w Warszawie 1903-1950, Warszawa 1970 , s. 162.

${ }^{82}$ „Nasza Księgarnia”, s. 22-26.

${ }^{83}$ H. Kister: Pegazy na Kredytowej, Warszawa 1980, s. 59-60.

W. Kocyba-Kamińska: Oficyna ossolinska w latach 1920-1939, Wrocław 1973, s. 51, 74,110 .

${ }^{85} \mathrm{~Np}$. samodzielnie opracowywali projekty książek (dobór papieru, czcionek, ilustracji, oprawy, etc.) znany z artystycznego smaku Jakub Mortkowicz oraz jeden z szefów Gebethnera i Wolffa - Józef Augustyn Wolff. M. Mlekicka: Jakub Mortkowicz..., s. 183; J. Okopień: Międzywojenni wydawcy: Gebethner $i$ Wolff, Wydawca 1995, nr 3, s. 33.

${ }^{86}$ A. Chodkowska: Towarzystwo Wydawnicze "Rój” 1924-1939, Warszawa 1986, s. $49-57$

${ }^{87}$ M. Mlekicka: Jakub Mortkowicz..., s. 139-157.

${ }^{88}$ K. Dolindowska, op. cit., s. 75-76.

${ }^{89}$ Przeglad Ksiegarski 1938, nr 5, s. 45; nr 11, s. 126.

${ }^{40}$ Wybitni introligatorzy oprawiali jedynie te dzieła, które wydawane były na papierach czerpanych lub tzw. egzemplarze reprezentacyjne. Oprawy nakładowe wykonywano po 1929 r. we własnej introligatomi, a wcześniej zlecano te prace zakładom rzemieślniczym. M. Mlekicka: Jakub Mortkowicz..., s. 183.

91 Slownik pracowników ksiqż̇ki polskiej, s. 355.

${ }^{92}$ Przeglad Ksiegarski 1939, nr 7, s. 68.

${ }^{93}$ M. Pieczonka, op. cit., s. 39, 93.

${ }^{4}$ Uważa się, że zwyczaj ten wprowadził w Polsce (na wzór wydawnictw niemieckich i francuskich) F. Hoesick. J. Okopień: Międzywojenni wydawcy: Ferdynand Hoesick, Wydowca 1995, nr 9, s. 30.

${ }^{95}$ Druki takie wydawały np. Ossolineum, Wydawnictwo J. Przeworskiego, IW „Nasza Księgarnia".

\% Np. prospekty Wydawnictwa J. Mortkowicza, Gebethnera i Wolffa, Towarzystwa Wydawniczego „Rój”.

${ }^{97}$ Np. M. Arcta.

${ }^{98}$ Np. prospekty Księgami TEiM, Księgarni Św. Wojciecha, Księgarni F. Hoesicka.

${ }^{99}$ Lepsze papiery miały np. prospekty Księgarni Św. Wojciecha czy „Roju”.

${ }^{100} \mathrm{~Np}$. Wydawnictwa J. Mortkowicza czy Wydawnictwa M. Arcta. 
${ }^{101}$ Np. prospekty Wydawnictwa J. Przeworskiego, TW „Rój”, Księgarni Trzaski, Everta i Michalskiego.

${ }^{102}$ Np. Książnicy Atlas czy Gebethnera i Wolffa.

${ }^{103}$ Np. ulotki IW „Biblioteka Polska”.

${ }^{104}$ Fakt, iż księgarze korzystali w dużej mierze z ulotek wydawców potwierdza prośba, jaką wystosowali oni do firm wydawniczych w 1929 r. na łamach Przeglaqdu Księgarskiego. Prosili, aby wydawcy uzgodnili między sobą jeden format druków rozsyłanych do księgarm, gdyż dotychczasowe ulotki „... odznaczaja się niezwłkła rozmaitościa formatów. przyprawiającq o rozpacz przeciętnego sortymentystę, ktory chcialby je dla własnej informacji kolekcjonować razem. (...) Księgarniom sortymentowym (...) dla ich informacji i użytku wewnętrznego nadsylajcie, panowie wydawcy, komunikaty w' formacie pocztówki normalnych rozmiarów' na dostatecznie sztywnym papierze". Przegląd Księgarski 1929, nr 2 , s. 27.

${ }^{105}$ Stanowią większość z odnalezionych druków reklamowych (601).

${ }^{106}$ Nie zawsze były one dobrze wykorzystywane, niektórzy księgarze nie interesowali się nadchodzącymi katalogami, ani nie starali się rozpowszechnić ich wśród klientów. Przegląd Księgarski publikował nawet specjalne artykuły, które miały wskazać sortymentystom pożytki płynące $\mathrm{z}$ wykorzystywania katalogów i namawiał ich do zamawiania większej ilości katalogów u wydawców „(...) nie po to jednak, by lezaty na pótkach i po jakimś czasie szły do kosza, lecz by celowo i planowo rozdawać i rozsylać klientom." [Przeglad Ḱsięgarski 1929, nr 7, s. 120-121] W następnym dziesięcioleciu jednak przyjrzano się bardziej krytycznie oferowanym przez wydawców katalogom i zaczęto dostrzegać, dlaczego cieszą się one tak niewielkim zainteresowaniem wśród księgarzy: "Cóż bowiem obecny przeciętny katalog daje sortymentyście? Bardzo niewiele. Jeśli księgarz lub klient nie znajqq danej ksiqżki, to katalog im jej nie zbliży; wada bowiem naszych katalogów jest to, że nie podaja wszystkich danych, potrzebnych do zorientowania się $w$ charakterze ksiqżki, jej rozmiarach treści i poziomie. Często trudno się nawet zorientować, kto dana ksiażkę napisal; wiele bowiem katalogów podaje tylko nazwisko autora bez imienia i țtulów osobistych, sam zaś tytut glón'ny często nie obrazuje nawet treści. (...) Jedlna konkretna jego wartość, w formie aktualnej ceny wydawnictwa, jest szczególem drugorzędnum (...)." [W. Lewelt: Oracjonalne katalogi ksiegarskie. Przeglad Księgarski 1938, nr 9, s. 90] Istotnie większość katalogów zawierała następujące informacje: nazwisko autora, inicjał imienia, tytuł główny książki i cenę. Rzadko spotyka się dane dotyczace roku i miejsca wydania, wydawcy i formatu. Prawie w ogóle nie stosowano opisów pelnych i adnotowanych. Często natomiast stosowany układ alfabetyczny nie ułatwiał orientacji w prezentowanej ofercie. W tej sytuacji istotnie lepszą informację o książce uzyskać można było z periodyków czy innych druków reklamowych (prospektów, ulotek).

${ }^{107}$ W. Lewelt , op. cit., Przeglaqd Księgarski 1938, nr 9, s. 90

${ }^{108}$ Przeglad Księgarski 1929, nr 51, s. 802

${ }^{109}$ Przeglad Ksiegarski 1938, nr 10, s. 113

${ }^{110} \mathrm{O}$ czytelni tej, jej właścicielce i jej ewentualnych związkach $\mathrm{z}$ wydawnictwem nic bliżej nie wiadomo.

${ }^{111}$ K. Dolindowska, op. cit., s. 129, 131

${ }^{112}$ Rola tego rodzaju reklamy znacznie wzrastała, w przypadku wysyłki książek na prowincję czy w odległe zakątki kraju, gdzie nie docierała regularnie prasa i brak było profesjonalnych księgarń. Dodatkową zaletą takich reklam byla ich niezwykła trwałość - spełniały 
one swoją rolę niemal tak dhugo jak istniała książka (z biegiem czasu funkcja ta zmieniała się $\mathrm{z}$ reklamowej na informacyjna).

113 W latach 1926-1927 nadawano głównie muzykę „na żywo". Moda na koncerty z płyt pojawiła się dopiero w 1928 r. M. Kwiatkowski: „, Tu Polskie Radio Warszawa... ", Warszawa 1980 , s. 116.

${ }^{114}$ M. Kwiatkowski: Radiostacje i rozglośnie Warszawy międzyw'ojennej. [W:] Warszawa II Rzeczypospolitej, z. 1, Warszawa 1968, s. 359.

115 Tenże: „Tu Polskie Radio....", s. 110, 141.

${ }^{116}$ W 1931 r. dokonano prób nagrań w Wilnie, wykorzystując austriackie urządzenia firmy „Melograph” utrwalające dźwięk na płytach żelatynowych. Metoda ta nie upowszechniła się jednak. Tamże, s. 187, 210.

${ }^{117}$ M. Kwiatkowski: „Tu Polskie Radio... ”, s. 118, 198.

${ }^{118}$ A. Zawada, op. cit., s. 194-195.

${ }^{119}$ W. Ślusarski: Poczatki radia i radiowej reklamy. Aida-media 1996, nr 9, s. 9.

${ }^{120}$ M. Kwiatkowski: „,Tu Polskie Radio... ”, s. 236-237, 245-254.

${ }^{121}$ Tamże, s. 313.

${ }^{122}$ W. Kocyba-Kamińska, op. cit., s. 58-60.

${ }^{123}$ Wiadomości Widawnicze PTWK 1938, nr 3/4, s. 1.

124 Przeglad Ksiegarski 1938, nr 4, s. 34.

${ }^{125}$ E. Paruszewska-Cwikiel, op. cit., s. 79.

${ }^{126}$ Przeglad Księgarski 1938, nr 6, s. 52.

${ }^{127}$ K. Konarska, op. cit., s. 38; Wiadomości Księgarskie 1931, nr 2, s. 1.

${ }^{128}$ M. Kwiatkowski: „,Tu Polskie Radio...”, s. 121.

129 W. Ślusarski, op. cit., s. 8-9.

${ }^{130}$ Maciej Józef Kwiatkowski, najwybitniejszy historyk Polskiego Radia, znał tylko jeden tekst programu „Rozmaitości”, który jak pisał „zachował się szczęśliwym trafem” (notabene w jego prywatnych zbiorach). Należy więc sądzić, że nie zachowały się inne teksty reklam, tym bardziej, że Archiwa PR zostały zniszczone w czasie wojny, a ponadto reklamy na ogół czytano „na żywo". W ogóle z nielicznych przedwojennych nagrań ocalało bardzo niewiele (np. tylko jedno słuchowisko - „Most” Ignacego Fika), głównie w Rozgłośni Krakowskicj. Jeżeli zaś chodzi o archiwizację reklam, to wg W. Slusarskiego rozpoczęto ją dopiero ok. 1990 r. M. Kwiatkowski: „, Tu Polskie Radio... ", s. 204, 375; W. Ślusarski, op. cit., s. 9

${ }^{131}$ Przegląd Księgarski 1929, nr 51, s. 802.

${ }^{132}$ Zwycięstwo PZWDziCz było jednak pyrrusowe: PR zastrzegło sobie prawo działalności reklamowej opartej „na wymianie świadczeń". Dotyczyło to reklamy wynikającej z ,racji programowej działalności PR" - a więc kontaktów $z$ fabrykami płyt i instrumentów muzycznych, dostawcami przyrządów akustycznych oraz sklepami handlującymi nimi. Radio zastrzegało sobie także prawo reklamy, „gdy wymiana świadczeń wynika z propagandowych czynności Polskiego Radia (premie w konkursach itp.), działalności społecznej (ogłoszenia w zamian za nagrody)", z tym, że PR zobowiązało się ograniczyć nagrody i firmy je oferujące do przemysłu radiotechnicznego oraz do takich artykułów i firm, ,których rozpowszechnianie ma znaczenie gospodarcze z punktu widzenia interesów państwa (rowery, motocykle), kulturalno-oświatowe (np. książki) lub przyczynia się do rozwoju sportu (np. kajaki)". Radio utrzymywało także prawo reklamowania instytucji i przedsiębiorstw państwowych, zleconego przez władze państwowe (PKO, Monopole Państwowe, Loteria 
itp.). M. Kwiatkowski: , Tu Polskie Radio...", s. 221-226, 417.

${ }^{133}$ A. Zawada, op. cit., s. 138.

${ }^{134}$ B. Wysocka: Kultura literacka Wielkopolski w latach 1919-1939, Poznań 1990, s. 96

${ }^{135}$ Encyklopedia Warszawy, Warszawa 1994, s. 180.

${ }^{136}$ Kino 1930, nr 15, s. 3.

${ }^{137}$ Przeglad Literacki 1930, nr 11/12, s. 3.

${ }^{138}$ Tygodnik Ilustrowany 1929, nr 41, s. 798.

${ }^{139}$ A. Chodkowska, op. cit., s. 54.

${ }_{140}$ M. Mlekicka: Jakub Mortkowicz..., s. 110-112; S. Arct: Okruchy..., s. 496-503.

${ }^{14 \mid}$ M. Mlekicka: Jakub Mortkowicz..., s. 112: M. Mlekicka: Wydawnictwo ..., s. 98.

${ }^{142}$ M. Pieczonka pisze, iż pierwszą polską wystawą w jakiej firma brała udział była prezentacja książek w Resursie Obywatelskiej w Warszawie w 1923 r. (1-4.XI). Sądzę jednak, że należy zaufać tu Muszkowskiemu, który wystawę tę opisywał z autopsji, jak równicż katalogowi wystawy. M. Pieczonka: Księgarnia Wyclawnicza ..., s. 160; J. Muszkowski: Wystawa Druków Polskich w Warszawie, kwiecień-maj-czerwiec 1922, Warszawa 1922, s. 24; Wystawy druków polskich, od pierwszych zaczatków tloczenia w kraju, aż po lata ostatnie, roku 1922 katalog systematyczny z indeksem abecadlowym, Warszawa 1922, s. 117-133.

${ }_{143}$ M. Mlekicka: Jakub Mortkowicz..., s. 112.

144 Wg B. Dybicz wystawy te organizowano w latach 192 I-1928. B. Dybicz, op. cit., s. 28; M. Pieczonka: Księgarnia Wvdawnicza..., s. 160-161, 191; Księgarz 1925, nr 4, s. 1.

${ }^{145}$ H. Mortkowicz-Olczakowa, op. cit., s. 268; Ksiegarz 1925, nr 4, s. 3.

${ }^{146}$ Nagrody dla krytyków były pieniężne, oficyny zaś nagrodzono dyplomami z miedziorytami M. Byliny. Pierwszą nagrodę spośród wydawców otrzymał J. Mortkowicz za 4 książki: „Popioły”, „Wisłę” i „Puszczę jodłową" S. Żeromskiego oraz za „Polską sztukę dekoracyjną" J. Warchałowskiego, a także za całokształt pracy wydawniczej. Drugą nagrodą wyróżniono IW „Biblioteka Polska” za „Legendę” W. Reymonta oraz „Dzieła malarskie” S. Wyspiańskiego, trzecią dostała Książnica-Atlas za „Książkę polską we Lwowie w XVI wieku" A. Jędrzejowskiej. Swiat Ksiqżki 1929, nr 6, s. 25-27; M. Mlekicka: Jakub Mortkowicz..., s. 113.

${ }^{147}$ Zarówno na wystawie z okazji dziesięciolecia państwa polskiego w Resursie Obywatelskiej w 1928 r., jak i na Powszechnej Wystawie Krajowej w Poznaniu, całość księgarskiego pokazu zaprojektował plastyk i architekt Czesław Knothe. H. Mortkowicz-Olczakowa, op. cit., s. 252.

${ }^{148}$ Ksieggarz 1929, nr 3, s. 60-61; J. Muszkowski: Przewodnik po grupie "Ksiażka” Powszechnej Wystawy Krajowej w Poznaniu, Warszawa 1929; J. Muszkowski: Z dziejów firmv Gebethner i Wolff (1857-1937), Warszawa 1938, s. 28.

${ }^{149}$ M. Mlekicka: Jakub Mortkowicz..., s. 115; J. Muszkowski: Z dziejów firmy..., s. 28.

${ }^{150}$ Autor katalogu wystawy, Przecław Smolik, ubolewal nad nieobecnością reprezentantów „Roju”, Księgarni Św. Wojciecha, Książnicy-Atlasu, Ossolineum i Księgarni F. Hoesicka. Ta lista nieobecnych jest bardzo wymowna. M. Mlekicka: Wydawnictwo.., s. 101; M. Mlekicka: Jakub Mortkowicz..., s. 115; P. Smolik: Wystawa Wspólczesnej Ksiqżki i Grafiki Polskiej w Lodzi, Kraków 1931, s. 4-6.

${ }^{15 !}$ Katalog Wystowy Pięknej Ksiqżki Polskiej urzqdzonej z powodu IV Zjazdu Bibljotekarzy' Polskich w Warszawie 31 maja-15 czerwca, Warszawa 1936, s. 7.

Is2 M. Mleķicka: Jakub Mortkowicz..., s. 115-116; Katalog Wystawy Pięknej Książki Polskiej..., s. 70 . 
${ }^{153}$ Wiadomości Księgarskie 1931, nr 10, s. 8

${ }^{154}$ W. Kocyba-Kamińska: Oficyna ossoliniska..., s. 173-174.

${ }^{155}$ Przegląd Księgarski 1937, nr 24, s. 259

${ }^{156}$ E. Paruszewska-Ć.wikiel nazywa całą tę akcję ogólnopolską wystawą. B. Wysocka, op. cit., s. 105; E. Paruszewska-Ćwikiel, op. cit., s. 79; W. Kocyba-Kamińska: Oficyna ossolińska..., s. 175.

${ }^{157}$ W. Kocyba-Kamińska używa nazwy Międzynarodowy Jarmark Książki. M. Mlekicka: Wy dawnictwo..., s. 90; W. Kocyba-Kamińska, op. cit., s. 174; M. Pieczonka: Ksiegarnia Widawnicza..., s. 162.

Is8 M. Mlekicka: Jakub Mortkowicz..., s. 101-102.

${ }^{154}$ Mortkowicz, komisarz sekcji polskiej na tejże wystawie, wspominał z rozgoryczeniem: "Jako komisarz sekcji polskiej urzadzalem wystawę przy pomocy shuzacego Wlocha, przydzielonego mi z ramienia konsulatu. Inne delegacje przywiozły ze sobq architektów dekoratorów. Tu - wobec braku środków - trzeba bylo zakasać rękauv i samemu stanać do pracy." Za: H. Mortkowicz-Olczakowa, op. cit., s. 251.

${ }^{160}$ Dosłownie. Córka Mortkowicza wspominała: ,... przydzielony ojcu do pomocy robotnik wloski (...) nie chcial się zbytnio fatygować. Kied. trzeba było powiesic wysoko na ścianie kilimv, a pod nimi portrety trzech pisarzy: Sienkiewicza, Reymonta i Żeromskiego, odmówil wprost, twierdzac, że się boi spaść. - Jestem starszy, a niczego się nie boję i zrobię to sam - oświadczyl wtedy ojciec. I rzeczywiście sam (...) wdrapal się na drabinę i powbijal uszystkie gwoździe. Inni robotnicy przyszli z sqsiednich sal popatrzeć na to dziwo. Ojciec nie mial wtedy jeszcze pięcdziesięciu lat, ale ze swa siwa brodq wygladal na o wiele starszego. Toteż jeden z widzów oswiadczyt z uznaniem, wskazując na zawieszony wlasnoręcznie przez ojca portret siwobrodego Henryka Sienkiewicza : - To dobrze, że pan powiesil tutaj su'ój portret. Zastużyl pan na to. Myśmy widzieli, jak się pan napracowal !". H. Mortkowicz-Olczakowa, op. cit., s. 255.

${ }_{161}$ M. Mlekicka: Jakub Mortkowicz..., s. 102-103.

162 Tamże, s. 107-108.

I $\leqslant 3$ Jeden z bibliofilów polskich relacjonowat: ,Zdala pociagają nas swym oryginalnym kolorytem i ujęciem tematu prace Zofji Stryjenskiej, które niestety pomieszczono nad gablota z napisem ", Tschechoslovakei", podczas gdv nad polska gablotq wiszq rzeczy węgierskie." K. Hałaciński: Wrażenia z uycieczki do Lipska i Drezna odbytej latem 1927 roku, Kraków 1928, s. 7; M. Mlekicka: Wvdawnictwo..., s. 93.

1int M. Mlekicka: Wvdawnictwo..., s. 96.

${ }^{165}$ M. Mlekicka: Jakub Mortkowicz..., s. 109.

166 Tamże, s. 110.

${ }^{167}$ Doceniono i inne introligatornie, z którymi współpracował TEiM: dyplomy honorowe otrzymali B. Zjawiński i F.J. Radziszewski. Z. Paliszewski: Działalność księgarska..., s. 54; M. Pieczonka: Księgamia Wydawnicza..., s. 163.

${ }_{168}$ Przeglad Księgarski 1938, nr 3, s. 23

${ }^{169}$ Prezentowała na niej swój dorobek Spółdzielnia Księgarska „Książka”. K. Dolindowska, op. cit., s. 34.

${ }^{170}$ M. Mlekicka: Jakub Mortkowicz..., s. 109.

171 Wenty odbywały się najczęściej w okresie przedświątecznym. Organizowali je m.in. Wende i Mortkowicz. Z. Arct: Gawędy o księgarzach, s. 136; H. Mortkowicz-Olczakowa, op. cit., s. 141-142; 
${ }_{172}$ Przegląd Księgarski 1929, nr 51, s. 802-803.

${ }_{173}$ J. Okopień: Międzywojenni wydawcy: Ksiqżnica -Atlas, Wydawca 1997, nr 5, s. 51; Z. Arct: Gaw'ędy..., s. 134-135; Przeglad Księgarski 1929, nr 51, s. 803

174 W cytowanym artykule przypomina się, iż zwyczaj podpisywania książek dla klientów księgarń nie jest w Polsce całkowitym novum, albowiem: ,... jui w latach 1910-1912, (...) ksieggarnia Altenberga we Lwowie ulatwiala uzyskanie podpisu jednego z artystów, których dziela malarskie byly reprodukowane w „Albumie Malarstwa Polskiego". Również księgarnia B. Polonieckiego zapoznawala w ten sposób publiczność z L. Staffem." Przeglad Księgarski 1929, nr 51, s. 802-803.

${ }^{175}$ M. Pieczonka: Ksiegarnia Wydawnicza.., s. 177.

176 Wiadomości Literackie 1938, nr 49, s. 4; Wiadomoścj Literackie 1929, nr 47, s. 8.

${ }^{177}$ Reklamę umieszczono na drugiej stronie okładki w: Świat Ksiqziki 1929, nr 6.

${ }^{178}$ Reklamy powieści Stanisława Piętaka „Młodość Jasia Kunefała” nagrodzonego przez PAL; Przeglad Księgarski 1938, nr 3, s. 23; Kurjer Poranny 1938, nr 32, s. 2; Wiadomości Lilerackie 1938, nr 7, s. 6.

${ }^{174}$ Ilustrowany Kurier Codzienny 1938, nr 94, s. 7.

${ }^{18 n}$ Ogłoszono wówczas, w porozumieniu z ZKP „Tydzień Goetlowski”, nawoływano do dekorowania witryn księgarskich książkami laureata, wydanymi oczywiście przez Gebethnera i Wolffa, wydrukowano stosowny plakat i opaski, przygotowano w setkach egzemplarzy reprodukcję portretu Goetla. Specjalne udogodnienia przygotowano dla firm księgarskich chcących zaopatrzyć się w dzieła pisarza w Komis-Hurcie Gebethnera i Wolffa. Przeglad Ksiegarski 1929, nr 51, s. 802.

${ }^{181}$ Niezwykle ostro skomentował np. skład i działalność Polskiej Akademii Literatury Stanisław Lam, wieloletni rcdaktor edycji Trzaski, Everta i Michalskiego: „Naturalnie któż to w'szedl do Akademii? Czy nestor pisanzy Aleksander Swiętochowski, najzashizeńszy historyk literatury Aleksander Briickner; największy z liryków Kazimierz Tetmajer, najbardziej znany z pisarzy rewolucyjnych Andrzej Strug? Bynajmniej! Zalażkiem byli czterej: kręcacy wszvstkim Juliusz Kaden-Bandrowski, dziecinniejacy, niemniej pożqdajqcy zaszczytów' Sieroszewski, glośny i rozpychający się Ferdynand Goetel i zaw'sze snobistycznie usposobiony Zenon Miriam-Przesmycki. (...) Wybuchaty skandale. Ustepowalijedni czlonkowie, inmych powolywano. Trwal Sieroszewski, mimo ze w jego Beniowskim wykazano mu cale stronice przepisywane żywcem z materiałów: Dokumentnie ośmieszyl się, broniąc się przed plagiatem z Grimmów tym, iż nigdy nie czytał thch giośnych pisarzy niemieckich. Nie czvtal, i koniec! Bajki opowiadala mu niania $i$ wedlug tej wersji je pisal! O ironio! Prezes Akademii Literatury (...) nie zna arcydziel tego rodzaju literackiego, w którym chce tworzyć, izasłania się nianiq! Cóż dziwnego, że tak poważny pisarz jak Roztworowski ostentacyjnie zrezygnowal z czlonkostwa w Akademii, ze odznaczeni wawrzynami (m.in. Ignacy Chrzanowski) odsylajq te niezaszczytne blaszki." S. Lam, op. cit., s. 389-390.

${ }^{182}$ M. Trzcińska, op. cit., s. 20.

${ }^{183}$ Bony te wprowadzono w 1929 r. M. Mlekicka: Wydawnictwo..., s. 62.

${ }^{1 \times 4}$ Bony miały na pierwszej stronie napis „Najserdeczniejsze życzenia w dniu ... przesyła..." i były zdobione przez wybitnych artystów, m.in. umieszczał na nich drzeworyty S. Ostoja-Chrostowski. Ksiegarz 1938, nr 12, s. 190; Express Poranny 1938, nr 342, s. 4; ${ }^{185}$ Z. Paliszewski, op. cit., s. 68-69; Z. Arct, op. cit., s. 97-98.

${ }^{186}$ M. Mlekicka: Jakub Mortkowicz..., s. 69.

${ }^{187}$ A. Chodkowska, op. cit., s. 103-104. 
${ }^{188}$ K. Dolindowska, op. cit., s. 32.

189 Swiat Książki 1929, nr 6, s. 32.

${ }^{190}$ E. Zawadzka, op. cit., s. 105-107.

${ }^{191}$ A. Chodkowska, op. cit., s. 102-103.

192 Jeżeli nabywca prenumerował obie serie, wówczas koszt pierwszej obniżano do $90 \mathrm{zł}$ za komplet oprawny i 64 zł za zeszytowy, płatne w ratach tygodniowych odpowiednio 2 zł 50 gr. lub 1 zł 50 gr. M. Mlekicka: Wydawnictwo..., s. 61 .

${ }^{143}$ Tamże.

${ }^{144}$ M. Pieczonka: Księgarnia Widannicza..., s. 29, 39, $41-42$.

${ }^{145}$ Ilustrowany Kurier Codzienny 1929, nr 34, s. 13.

196 Ilustrowany Kurier Codzienny 1938, nr 94, s. 7.

${ }^{197}$ E. Zawadzka, op. cit., s. 108.

${ }^{198}$ Przy tytułach w cenie 50-100 zł rata wynosiła $8 \mathrm{zl}, 100-200 \mathrm{zl}$ - rata $10 \mathrm{zl}, 200-300 \mathrm{zl}$ - rata $15 \mathrm{zł}, 300-400 \mathrm{zł}$ - rata $20 \mathrm{z} \nmid$ i $400-500 \mathrm{zł} \mathrm{-} \mathrm{rata} 25 \mathrm{zł}$ miesięcznie. M. Pieczonka: Ksiegarnia Wvdawnicza.., s. 171.

${ }^{149}$ M. Pieczonka: Księgarnia Wvdawnicza.., s. 170-173.

${ }^{200}$ M. Mlekicka: Jakub Mortkowicz..., s. 69-70.

${ }^{201}$ B. Dybicz, op. cit., s. 54.

202 1. Majerowiczowa: Wysylkowa sprzedaz ksiqzek $w$ Polsce w latach międzywojennvch, Księgarz 1971, nr 3, s. 7, 9 oraz druki reklamowe wydawców (J. Przeworskiego i Księgarni Św. Wojciecha).

${ }^{203}$ W sprawie zniżki opłat pocztowych, Przegląd Księgarski 1929, nr 3, s. 59-60.

${ }^{204}$ E. Zawadzka, op. cit., s. 104-105.

${ }^{205}$ 1. Majerowiczowa, op. cit., s. 10-11.

${ }^{206}$ E. Zawadzka, op. cit., s. 106.

207 Świat Ksiqżki 1929, nr 6, s. 32.

${ }^{208} \mathrm{~K}$. Dolindowska, op. cit., s. 133.

${ }^{209}$ Tylko do połowy 1926 r., kiedy to Przeglad Sportowy kupiła „Prasa Polska”. K. Konarska, op. cit, s. 73.

${ }^{210}$ A. Chodkowska, op. cit., s. 104-106.

$2^{11}$ W. Kocyba-Kamińska, op. cit., s. 57 - 60.

${ }^{212}$ Z. Paliszewski, op. cit., s. 68.

213 Z. Arct, op. cit., s. 47.

${ }^{214}$ Tamże, s. 95-96.

${ }^{21.5}$ L. Marszalek: Polskie Towarzystwo Wydawców Ksiqżek w latach 1921-1945, Editor 1988 , t. 1, s. 148-149.

${ }^{216}$ E. Zawadzka, op. cit., s. 62.

${ }^{217}$ Wspomnienia Anny Rudowskiej w: A. Bogdański: Ocalić od zapomnienia, Księgarz 1978, nr 1, s. 53.

${ }^{218}$ E. Zawadzka, op. cit., s. 64.

${ }^{219}$ Przeglad Ksieggarski 1929, nr 5, s. 79.

${ }^{220}$ A. Chodkowska, op. cit., s. 107-110.

${ }^{221}$ B. Dybicz, op. cit., s. 53, 58.

${ }^{222}$ Kurjer Ksiegarski 1936, nr 18, s. 4; Wiadomości Literackie 1938, nr 38, s. 8.

${ }^{223}$ Z. Arct, op. cit., s. 78; H. Kister, op. cit., s. 80.

${ }^{224}$ Przeglad Księgarski 1938, nr 3, s. 24. 
${ }^{225} \mathrm{~Np}$. Gebethner i Wolff w 1929 r. informował na łamach prasy: „Od dnia 10 IV r.b. zostaje podwyższona cena dzieła „Kobieta lekarką domową”. Do dnia tego ekspedjować będziemy po starych cenach.”. Przeglad Ksiegarski 1929, nr 11, s. 215.

${ }^{226}$ W 1925 r. dziękowano Gebethnerowi i Wolffowi za przekazanie 350 tomów, a w 1926 tejże firmie za cenną inicjatywę wysyłania do związkowej biblioteki 2 egzemplarzy każdego tytułu. Ksiegarz 1925, nr 2, s. 27; Księgarz 1926, nr I s. 39.

${ }^{227}$ Przeglad Księgarski 1929, nr 21, s. 330.

${ }^{228}$ Przeglaqd Księgarski 1929, nr 50, s. 783.

${ }^{229}$ Przeglad Księgarski 1938, nr 19, s. 233.

${ }^{230}$ B. Dybicz, op. cit., s. 37.

${ }^{23 !}$ W. Kocyba-Kamińska, op. cit., s. 167-169.

${ }_{232} 150$ książek dla bibliotek wiejskich. Tygodnik Ilustrowany 1938, nr 23, s. 444.

${ }^{233}$ Przeglad Księgarski 1938, nr 6, s. 50-51.

${ }^{234}$ Przeglad Księgarski 1937, nr 13, s. 126.

${ }^{235}$ W. Kocyba-Kamińska, op. cit., s. 170-171. 